OPEN ACCESS

Edited by:

Daniel Merrifield,

Plymouth University, United Kingdom

Reviewed by:

Giuseppe Spano,

University of Foggia, Italy

Learn-Han Lee,

Monash University Malaysia, Malaysia

${ }^{*}$ Correspondence:

Zhigang Zhou

zhouzhigang03@caas.cn

Specialty section:

This article was submitted to

Aquatic Microbiology,

a section of the journal

Frontiers in Microbiology

Received: 17 February 2018

Accepted: 21 September 2018

Published: 12 October 2018

Citation:

Hoseinifar SH, Sun Y-Z, Wang A and

Zhou Z (2018) Probiotics as Means of

Diseases Control in Aquaculture, a

Review of Current Knowledge and

Future Perspectives.

Front. Microbiol. 9:2429.

doi: 10.3389/fmicb.2018.02429

\section{Probiotics as Means of Diseases Control in Aquaculture, a Review of Current Knowledge and Future Perspectives}

\author{
Seyed Hossein Hoseinifar ${ }^{1}$, Yun-Zhang Sun ${ }^{2}$, Anran Wang ${ }^{3}$ and Zhigang Zhou ${ }^{3 *}$ \\ ${ }^{1}$ Department of Fisheries, Faculty of Fisheries and Environmental Sciences, Gorgan University of Agricultural Sciences and \\ Natural Resources, Gorgan, Iran, ${ }^{2}$ Key Laboratory of Healthy Mariculture for the East China Sea, Ministry of Agriculture, \\ Fisheries College, Jimei University, Xiamen, China, ${ }^{3}$ Key Laboratory for Feed Biotechnology of the Ministry of Agriculture, \\ Feed Research Institute, Chinese Academy of Agricultural Sciences, Beijing, China
}

Along with the intensification of culture systems to meet the increasing global demands, there was an elevated risk for diseases outbreak and substantial loss for farmers. In view of several drawbacks caused by prophylactic administration of antibiotics, strict regulations have been established to ban or minimize their application in aquaculture. As an alternative to antibiotics, dietary administration of feed additives has received increasing attention during the past three decades. Probiotics, prebiotics, synbiotics and medicinal plants were among the most promising feed supplements for control or treatments of bacterial, viral and parasitic diseases of fish and shellfish. The present review summarizes and discusses the topic of potential application of probiotics as a means of disease control with comprehensive look at the available literature. The possible mode of action of probiotics (Strengthening immune response, competition for binding sites, production of antibacterial substances, and competition for nutrients) in providing protection against diseases is described. Besides, we have classified different pathogens and separately described the effects of probiotics as protective strategy. Furthermore, we have addressed the gaps of existing knowledge as well as the topics that merit further investigations. Overall, the present review paper revealed potential of different probiont to be used as protective agent against various pathogens.

Keywords: disease control, immune responses, probiotics, fish, shellfish

\section{THE INTERACTIONS BETWEEN PROBIOTICS AND DISEASES OF FISH AND SHELLFISH}

\section{Probiotics: Definition and History}

Nowadays, several types of beneficial feed additive such as probiotics, prebiotics, and synbiotics are being used in aquaculture to improve growth performance, immune responses and disease resistance as well as an alternative to antibiotics (Irianto and Austin, 2002; Hoseinifar et al., 2016, 2017b; Sayes et al., 2018). The term "probiotics" arose from the Greek words "pro" and "bios" meaning "for life"; generally referred to microbial feed additives which confer host organism through modulation of intestinal microbiota. Parker (1974) was the first who defined probiotics as organisms and substances that affect microbial in intestine. According to the Food and Agriculture Organization (FAO) and the World Health Organization (WHO), probiotics are live 
microorganisms which are used orally having some tangible health benefits to the host (Hotel and Córdoba, 2001). Considering the difference between environment in aquatic ecosystem and those terrestrial animals, a modified definition proposed for probiotics in aquaculture by Merrifield et al. (2010b) as, "a probiotic organism can be regarded as a live, dead or component of a microbial cell, which is administered via the feed or to the rearing water, benefiting the host by improving disease resistance, health status, growth performance, feed utilization, stress response or general vigor, which is achieved at least in part via improving the hosts microbial balance or the microbial balance of the ambient environment." The probiotics include different kinds of bacteria, bacteriophages, microalgae and yeast which have been widely used in aquaculture via water routine or feed supplement (Llewellyn et al., 2014) Currently, there are lots of commercially available probiotics in for of mono or multi-strains (Van Doan et al., 2017).

\section{Mode of Actions on Disease Resistance}

The extensive literature on probiotics revealed beneficial effects on host's gut defenses which has vital importance in diseases prevention as well digestive tract inflammation treatment (Azimirad et al., 2016; Modanloo et al., 2017). Apart from immunomodulation, probioticmicroorganisms, such as lactic acid bacteria, Brevibacillus brevis, Vagococcus fluvialis, and Vibrio harveyi (Lazado et al., 2011; Sugimura et al., 2011; Korkea-aho et al., 2012; Mahdhi et al., 2012; Sorroza et al., 2012), stick with the mucosal epithelium of gastrointestinal tract and help to resist pathogens (Luis-Villaseñor et al., 2011). In another way, probiotics increase feed digestibility through elevation of different digestive enzymes such as alginate lyases, amylases, and proteases (Zokaeifar et al., 2012). They also produce organic acids, fatty acids, biotin and vitamin B12, hydrogen peroxide, antibiotics, bacteriocins, siderophores, lysozyme (Sugita et al., 1991, 1992; Yan et al., 2002; Vine et al., 2006), which have positive effects on host health. Numerous studies have demonstrated that probiotics caused health benefits in aquatic organisms, such as Japanese flounder (Heo et al., 2013), black tiger prawns, Penaeus monodon (Rengpipat et al., 1998), whiteleg prawns (Chiu et al., 2007), and western king prawns (Hai et al., 2010).

\section{Modulation of Immune Parameters}

The first defense line against infections is innate immune responses (or non-specific immune responses) which include different cells and mechanisms that protect host organism from infectious diseases. It has been reported that probiotics can affect the elements of non-specific immune system such as mono-nuclear phagocytes (monocytes, macrophages) and polymorphonuclear leukocytes (neutrophils), natural killer (NK) cells etc. Previous studies revealed increment of leucocytes (Korkea-aho et al., 2012), monocytes (Aly et al., 2008b), erythrocytes, granulocytes, macrophage, and lymphocytes in various fishes following treatment with probiotics (Kim and Austin, 2006a,b; Nayak et al., 2007; Kumar et al., 2008). For instance, rainbow trout fed Clostridium butyricum showed increased resistance against vibriosis through affecting phagocytic activity of leukocytes (Sakai et al., 1995). Furthermore, dietary Bacillus sp. S11 positively affected cellular and humoral immunity in tiger shrimp (Penaeus monodon) which resulted in protection against disease (Rengpipat et al., 2000). Also, combined administration of Bacillus and Vibrio sp. in young white shrimp showed beneficial effects on growth performance, survival as well as resistance against $V$. harveyi and white spot syndrome virus (Antony et al., 2011). The authors attributed the protection to elevation of phagocytosis and antibacterial activity; indeed immunomodulation. Beside these results on shrimps, dietary Lactobacillus rhamnosus (ATCC 53103) (10 $0^{5}$ CFU $\left.\mathrm{g}^{-1}\right)$ increased the respiratory burst in rainbow trout (Oncorhynchus mykiss)(Nikoskelainen et al., 2003). Therefore, probiotics are beneficial bacteria which not only capable of inhibiting pathogens, but also regulating the host immune system. Probiotics possess conserved microbe-associated molecular patterns (MAMPs), including peptidoglycan (PGN), lipoteichoic acids (LTA), S-layer protein A (SlpA), exopolysaccharides (EPS), flagellin and microbial nucleic acids which can be recognized by certain pattern recognition receptors (PRRs), and induces a signaling cascade that can result in the production of cytokines, chemokines, and other effector molecules thus activating the immune response in the host (Bron et al., 2012; Remus et al., 2012). During past years, there was increasing interests toward determination of mode of action of probiotics on intestinal immune system. In this regard, the researchers evaluated the possible relationship between TLR signaling-mediated recognition of probiotics and activation of the intestinal immunity. For example, it has been reported that TLR2 signaling pathway was involved in recognition of probiotic Psychrobacter sp. SE6 and inducing subsequently immune responses in grouper Epinephelus coioides (Sun et al., 2014).

\section{Competition for Binding Sites}

Competitive exclusion has been suggested as a mode of action of probiotic in prevention of pathogens (Mahdhi et al., 2012; Sorroza et al., 2012); achieved by colonization of probiotics in GI mucosal epithelium (Macey and Coyne, 2006; Merrifield et al., 2010a; Lazado et al., 2011; Korkeaaho et al., 2012). Different types of surface determinants suggested to be involved in probiotis interaction with intestinal epithelial cells and mucus which per se prevents pathogens colonization (so called competitive exclusion). The primary reason for this could be competitions for adhesion receptors (Montes and Pugh, 1993) which can antagonize pathogens (Luis-Villaseñor et al., 2011) and reduce their colonization (Chabrillón et al., 2005). This clearly shows the potential of probiotics administration as a substitute for antibiotics and other chemicals (Cheng et al., 2014). It has been reported that passive forces, electrostatic interactions, hydrophobic, steric forces, lipoteichoic acids were among the factors which affect adhesion of probiotics to attachment sites (Wilson et al., 2011). Westerdahl et al. (1991) stated that competition for attachment sites and nutrients following occupying mucosal surfaces could be possible mode of action for protective effects of probiotic against pathogens. 


\section{Production of Antibacterial Substances}

In aquaculture, probiotics are used as an alternative to antibiotics and chemicals (Decamp et al., 2008; Van Hai et al., 2009; Heo et al., 2013). Though the mode of action through which probiotics exert antibacterial effects remained to be determined, many studies indicated that probiotics produced antibiotic compounds (Moriarty, 1998). Besides, reduce in $\mathrm{pH}$ following production of organic acids can inhibits growth of pathogenic bacteria (Ma et al., 2009). For example, Ramesh et al. (2015) reported antibacterial activity of Bacillus licheniformis and B. pumilus; which resist low $\mathrm{pH}$ and high bile concentrations. Another study with Bacillus licheniformis CPQB, revealed inhibition of Vibrio alginolyticus in whiteleg prawns (Ferreira et al., 2015). It has been demonstrated that Lactobacillus spp. (common probiotics) produce short chain fatty acids, diacetyl, hydro peroxide, and bactericidal proteins (Rengpipat et al., 1998; Verschuere et al., 2000; Faramarzi et al., 2011), which pre se improve immune responses as well as disease resistance (Raa, 1996; Gram et al., 1999). Consequently, probiotics can protect aquatic animals from challenge with pathogens by producing antibiotic compounds.

\section{Competition for Nutrients}

The competition of nutrients has been considered among the mechanisms through which probiotics inhibit pathogens (Ringø et al., 2016). Previous study has reported that competition for iron is an essential element in marine bacteria (Verschuere et al., 2000). The majority of bacteria need Iron for their growth. However, there is limited available of iron in the tissues and body fluids of animals (Verschuere et al., 2000). The siderophores which are iron-binding agents, help bacteria to obtain the necessary amount of Iron for their growth. There is direct relation between production of siderophore and virulence of some pathogens (Gram et al., 1999).

The beneficial effects of Gram-positive genus Bacillus on water quality in culture environment has been reported in previous studies (Rafiee and Saad, 2005; El-Haroun et al., 2006; Hai, 2015; Dawood and Koshio, 2016). It seems that genus Bacillus is more effectual for converting organic matter to $\mathrm{CO}_{2}$ as well as balancing phytoplankton production (Balcázar et al., 2006). It has been reported that supplemented F. vannamei feed with Bacillus sp., Saccharomyces cerevisiae, Nitrosomonas sp., and Nitrobacter sp. (a commercial product) could decrease the concent rations of inorganic nitrogen and phosphate from 3.74 to $1.79 \mathrm{mg} / \mathrm{L}$ and 0.1105 to $0.0364 \mathrm{mg} / \mathrm{L}$, respectively (Li et al., 2006).

In addition, probiotics also enhanced growth performance and feed utilization in aquatic animals through increasing digestive enzymes activity ( $\mathrm{Yu}$ et al., 2009; Zokaeifar et al., 2012; Hoseinifar et al., 2017a). For example, Van Hai et al. reported that dietary probiotics (Pseudomonas aeruginosa and Ps. Synxantha) enhanced western king prawn growth performance (Van Hai et al., 2009; Hai et al., 2010). Recently research by Faturrahman et al. also revealed dietary probiotic (Vibrio $\mathrm{Alg} 3.1 \mathrm{Rf}^{\mathrm{R}}$-Abn1.2Rf $\mathrm{R}^{\mathrm{R}}$-enriched protein) improved growth rate of Haliotis asinine (Rohyati, 2015). The incease of digestive enzyme activity and improvement of the digestive process following treatment with probiotic has been attributed to production of extracellular enzymes such as proteases, carbohydrolases and lipases (Arellano-Carbajal and Olmos-Soto, 2002; Leonel Ochoa-Solano and Olmos-Soto, 2006; Soleimani et al., 2012; Eshaghzadeh et al., 2015; Hoseinifar et al., 2015a,b). Furthermore, considering provision of vital nutrients like fatty acids, biotin and vitamins, probiotics might be a complementary food source (Verschuere et al., 2000).

\section{PROBIOTICS AND BACTERIAL DISEASES IN FISH (TABLE 1) \\ Gram-Positive Bacteria \\ Lactic Acid Bacteria}

Lactic acid bacteria (LAB) Gram positive, usually non-motile and non-sporing bacteria which mainly produce lactic acid during fermentation (Stanier et al., 1975). They were among the mostly studied probiotics (Merrifield et al., 2014). The extensive available literature revealed beneficial effects of LABs as probiotic on growth performance, immune responses and disease resistance shellfish (Ringø et al., 2010; Merrifield et al., 2014). Another important feature of these probiont strains is disease protection which has been reviewed in this section.

\section{Carnobacteria}

Carnobacteria have been frequently isolated from fish intestine (Merrifield et al., 2014). It has shown antagonistic activity against different kinds of fish pathogens (Ringø et al., 2010). The C. inhibens $\mathrm{K} 1$ isolated from Atlantic salmon (Salmo salar L.) digestive tract inhibited fish pathogens under in vitro condition (Jöborn et al., 1997), and subsequently study showed that dietary administration of $5 \times 10^{7}$ cells $\mathrm{g}^{-1} \mathrm{C}$. inhibens $\mathrm{K} 1$ for 14 days reduced mortalities caused by A. salmonicida, Vibrio ordalii and Yersinia ruckeri in Atlantic salmon and rainbow trout (Robertson et al., 2000). The C. divergens strain 6251, isolated from Artic charr (Salvelinus alpinus L.) foregut, showed growth-inhibitory effects against both Aeromonas salmonicida and Vibrio anguillarum in vitro (Ringø et al., 2002; Ringø, 2008). Also, dietary administration of $C$. divergens for 3 weeks reduced vibriosis caused by $V$. anguillarum in Atlantic cod ( $G$. morhua) fry (Gildberg et al., 1997). Kim and Austin (2006a) characterized two Carnobacteria isolates obtained from rainbow trout intestine (C. maltaromaticum B26 and C. divergens B33). Both strains stimulated non-specific immunity and demonstrated effectiveness against A. salmonicida and Y. ruckeri in vitro. Løvmo Martinsen et al. (2011) reported that C. maltaromaticum which was previously isolated from Atlantic cod hindgut chamber could, to a certain extent, outcompete $V$. anguillarum in an unidentified mechanism.

\section{Lactobacillus}

The application of probiotic Lactobacillus spp. in fish aquaculture has been extensively studied (Merrifield et al., 2010a; Merrifield and Carnevali, 2014). Lactobacillus (Lb.) acidophilus improved immune responses and resistance against Pseudomonas fluorescens and Streptococcus iniae in Nile tilapia (Aly et al., 2008a,b). Similarly, African catfish (Clarias gariepinus) juveniles were fed $L b$. acidophilus $\left(3 \times 10^{7} \mathrm{CFU} \mathrm{g}^{-1}\right)$ for 12 weeks $(\mathrm{Al}$ Dohail et al., 2011) and resistance against Staphylococcus xylosus, 
TABLE 1 | Overview of the effects of probiotics against pathogenic bacteria in fish.




TABLE 1 | Continued

\begin{tabular}{|c|c|c|c|c|}
\hline Probiotic & Pathogen or disease & Fish species & Beneficial effects & Reference \\
\hline \multirow[t]{2}{*}{ Clostridium butyricum } & vibriosis & Rainbow trout & Enhance disease resistance & Sakai et al., 1995 \\
\hline & vibriosis & Chinese drum & $\begin{array}{l}\text { Enhanced the phagocytic activity of } \\
\text { leucocytes and therefore disease } \\
\text { resistance to vibriosis }\end{array}$ & Pan et al., 2008b \\
\hline \multirow[t]{2}{*}{ Micrococcus luteus } & A. salmonicida & Rainbow trout & Better survival & Irianto and Austin, 2002 \\
\hline & A. hydrophila. & Nile tilapia & Reduction in mortalities & Abd El-Rhman et al., 2009 \\
\hline Rhodococcus sp. & V. anguillarum & Rainbow trout & Significantly better protection & Sharifuzzaman et al., 2011 \\
\hline Brochothrix thermosphacta & A. bestiarum & Rainbow trout & Protected against skin infections & Pieters et al., 2008 \\
\hline Kocuria sp. & V. anguillarum and $V$. ordalii & Rainbow trout & Reduction in mortalities & $\begin{array}{l}\text { Sharifuzzaman and Austin, } \\
2010\end{array}$ \\
\hline \multicolumn{5}{|c|}{ GRAM-NEGATIVE BACTERIA } \\
\hline Pseudomonas fluorescens & V. anguillarum & Rainbow trout & Reduced mortalities & Gram et al., 1999 \\
\hline Pseudomonas chlororaphis & Aeromonas sobria & Perch & Control Aeromonas sobria infection & Gobeli et al., 2009 \\
\hline Pseudomonas sp. & F. psychrophilum & Rainbow trout & Reduced mortalities & Korkea-aho et al., 2011 \\
\hline \multirow[t]{2}{*}{ Pseudomonas aeruginosa } & A. hydrophila & Rohu & $\begin{array}{l}\text { Significantly higher post-challenge } \\
\text { survival rates }\end{array}$ & Giri et al., 2012 \\
\hline & Vibrio parahaemolyticus & Zebrafish & $\begin{array}{l}\text { PROTECT fish by inhibiting biofilm } \\
\text { formation and enhancing defense } \\
\text { mechanisms }\end{array}$ & Vinoj et al., 2015 \\
\hline \multirow[t]{2}{*}{ Aeromonas hydrophila } & Aeromonas salmonicida & Rainbow trout & Reduce infections & Irianto and Austin, 2002 \\
\hline & Aeromonas salmonicida & Goldfish & Controls infection & Irianto et al., 2003 \\
\hline Aeromonas sobria & $\begin{array}{l}\text { Lactococcus garvieae and } \\
\text { Streptococcus iniae }\end{array}$ & Rainbow trout & Improve the disease resistance & \\
\hline Aeromonas sobria & Aeromonas bestiarum & Rainbow trout & $\begin{array}{l}\text { Protected rainbow trout against } \\
\text { challenge }\end{array}$ & Pieters et al., 2008 \\
\hline Aeromonas veronii & A. hydrophila & Common carp & Enhance disease resistance & Chi et al., 2014 \\
\hline \multirow[t]{3}{*}{ Shewanella putrefaciens } & Vibrio anguillarum & Gilthead seabream & Reduced mortalities & Chabrillón et al., 2006 \\
\hline & $\begin{array}{l}\text { Photobacterium damselae sub sp. } \\
\text { Piscicida }\end{array}$ & Senegalese sole & Improved survival & Diaz-Rosales et al., 2009 \\
\hline & $\begin{array}{l}\text { Photobacterium damselae sub sp. } \\
\text { Piscicida }\end{array}$ & Senegalese sole & Improved growth disease resistance & De la Banda et al., 2012 \\
\hline Shewanella xiamenensis & A. hydrophila & Grass carp & Improved disease resistance & Wu et al., 2015 \\
\hline Enterobacter cloacae & Yersinia ruckeri & Rainbow trout & High survival ratio & Capkin and Altinok, 2006 \\
\hline $\begin{array}{l}\text { Enterobacter amnigenus } \\
\text { Enterobacter sp. }\end{array}$ & Flavobacterium psychrophilum & Rainbow trout & Enhanced resistance to infection & Burbank et al., 2011 \\
\hline Enterococcus faecalis & Aeromonas salmonicida & Rainbow trout & Lower cumulative mortality & $\begin{array}{l}\text { Rodríguez-Estrada et al., } \\
2013\end{array}$ \\
\hline Roseobacter sp. & V. anguillarum & Turbot & Controlled V. anguillarum infection & Planas et al., 2006 \\
\hline $\begin{array}{l}\text { Phaeobacter (Roseobacter) } \\
\text { gallaeciensis }\end{array}$ & V. anguillarum & Cod larvae & $\begin{array}{l}\text { Reduced the mortality by } \\
\text { approximately } 10 \%\end{array}$ & D'Alvise et al., 2012 \\
\hline Roseobacter sp. & Vibrio anguillarum & Turbot & $\begin{array}{l}\text { Significant decrease in cumulative } \\
\text { mortality }\end{array}$ & Hjelm et al., 2004 \\
\hline Vibrio alginolyticus & A. salmonicida & Atlantic salmon & $\begin{array}{l}\text { Significant decrease in cumulative } \\
\text { mortality }\end{array}$ & Austin et al., 1995 \\
\hline Zooshikella sp. & Streptococcus inane & Olive flounder & $\begin{array}{l}\text { Improve the innate immune response } \\
\text { and control streptococcus inane } \\
\text { infections }\end{array}$ & Kim et al., 2010 \\
\hline Flavobacterium sasangense & A. hydrophila & Common carp & $\begin{array}{l}\text { Enhance immune response and } \\
\text { disease resistance }\end{array}$ & Chi et al., 2014 \\
\hline \multicolumn{5}{|l|}{ YEAST } \\
\hline Saccharomyces cerevisiae & Aeromonas hydrophila & Tilapia & Reduced mortality & Abdel-Tawwab et al., 2008 \\
\hline $\begin{array}{l}\text { Saccharomyces cerevisiae } \\
\text { var. boulardii }\end{array}$ & Y. ruckeri. & Rainbow trout & Improved disease resistance & Quentel et al., 2005 \\
\hline Debaryomyces hansenii & Aeromonas hydrophila & Leopard grouper & $\begin{array}{l}\text { Improved immune function and } \\
\text { disease resistance }\end{array}$ & Reyes-Becerril et al., 2011 \\
\hline
\end{tabular}


Aeromonas hydrophila gr2 and Streptococcus agalactiae $\left(2 \times 10^{6}\right.$ $\mathrm{CFU} \mathrm{ml} \mathrm{m}^{-1}$ intraperitoneal injection) were tested which revealed elevated resistance. Likewise, feeding rainbow trout with $L b$. rhamnosus ATCC $53101\left(10^{9}\right.$ cells $\left.^{-1}\right)$ for 51 days resulting in a reduction of mortalities by $A$. salmonicida from $\sim 53 \%$ to $\sim 19 \%$ (Nikoskelainen et al., 2001). Furthermore, dietary supplemented with $10^{8} \mathrm{CFU} \mathrm{g}^{-1}$ and $10^{10} \mathrm{CFU} \mathrm{g}^{-1} \mathrm{Lb}$. rhamnosus for 14 days protected tilapia (Oreochromis niloticus) from acute septicemic death by experimental Edwardsiella tarda infection (Pirarat et al., 2011). Rainbow trout fed $L b$. plantarum CLFP 238 at $10^{7}$ CFU $\mathrm{g}^{-1}$ of feed for 30 days showed a dramatic reduction in mortalities when challenged with pathogenic Lactococcus ( $L c$.) garvieae (Vendrell et al., 2008). Salinas et al. (2008) reported that Lactobacillus delbrueckii sp. lactis (CECT 287, Valencia, Spain) prevented A. salmonicida damaging effects in the foregut of Atlantic salmon. Likewise, a study on Gilthead seabream revealed $L b$. rhamnosus and Bifidobacterium lactis notably reduced colonization of the pathogenic bacteria ( $V$. anguillarum, Photobacterium damselae ssp. piscicida, V. alginolyticus, and Vibrio harveyi) (Chabrillon et al., 2006). It was also observed that L. plantarum, isolated from rainbow trout intestinal mucosa, could upregulate immune related genes expression and increase resistance against $L c$. garvieae (Pérez-Sánchez et al., 2011). Feeding rock bream (Oplegnathus fasciatus) with $L b$. sakei BK19 $\left(2.2 \times 10^{7} \mathrm{CFU} \mathrm{g^{-1 }}\right)$ resulted in non-significant decrease of mortality after challenge with Edwardsiella tarda (Harikrishnan et al., 2011). Also, Lb. pentosus PL11 improved immune responses as well as resistance of Japanese eel (Anguilla japonica) against Edwardsiella tarda (Lee et al., 2013). To test the protective effects of dietary supplementation of highly adhesive Lactobacillus brevis JCM 1170 (HALB) and less-adhesive $L b$. acidophilus JCM 1132 (LALB) against the tilapia pathogen, A. hydrophila NJ-1, fish were immersed in strain NJ-1 for 14 days without supplemented feed. The results showed that diet containing $10^{9}$ cells $\mathrm{g}^{-1}$ of strain HALB/g feed (B3) showed significantly lower mortality (Liu et al., 2013). Recently, Beck et al. (2015) evaluated the mixture or single application of two host associated probiotics include Lc. lactis BFE920 isolated from bean sprout and $L b$. plantarum FGL0001 isolated from olive flounder (Paralichthys olivaceus) hindgut, in olive flounder. After challenge with Streptococcus iniae ( $\log _{10} 6.0 \mathrm{CFU} / \mathrm{fish}$ ), the survival rate in the groups fed mixed probiotics and $L b$. plantarum FGL0001, and the control were 55, 45, 35, and 20\%, respectively. In a comparative view, it seems that $L b$. plantarum was the most efficient Lactobacillus species in terms of disease bio-control. As the -aforementioned studies revealed, this species substantially improved resistance against various pathogenic bacteria. Besides disease protection, the species showed beneficial effects on growth performance and immune parameters (Van Doan et al., 2017). Hence, $L b$. plantarum can be suggested as a promising tool for disease control in aquaculture.

\section{Lactococcus}

Balcázar et al. (2007) isolated Lc. lactis subsp. lactis (CLFP 100) and Lc. lactis subsp. cremoris (CLFP 102) from rainbow trout intestine. Subsequently, in a separate study, they administered Lc. Lactis in rainbow trout diet and observed increased immune parameters as well as protection against furunculosis (Balcázar et al., 2007). The same results observed with brown trout (Salmo trutta) challenged with Aeromonas salmonicida (Balcázar et al., 2009). Kim et al. (2013) reported that Lc. lactis BFE920 inhibits the growth of different pathogens including Streptococcus iniae, S. parauberis, Enterococcus viikkiensis as well as Lactococcus garviae under in vitro condition. The same authors supplemented olive flounder (Paralichthys olivaceus) diet with Lc. lactis BFE920 and after 2 weeks feeding observed activated the innate immune system which resulted in protection against $S$. iniae infection in both in experimental condition and large scale field condition. In accordance, Heo et al. (2013) reported that dietary $L c$. lactis $\left(10^{8} \mathrm{CFU} \mathrm{g}^{-1}\right)$ elevated serum immune parameters (e.g., lysozyme, antiprotease, serum peroxidase, and blood respiratory burst activities) as well as resistance against $S$. iniae in olive flounder. Recently, Beck et al. (2015), in an study with olive flounder, observed that dietary administration of mixed probiotic Lb. plantarum FGL0001 and Lc. lactis BFE920, or single Lc. lactis BFE920 for 30 days could improve the survival rates after challenged with S. iniae. An overview of different Lactococcus spp. revealed that the main focus was on Lc. Lactis and this species was capable of protecting different fish species against bacterial pathogens.

\section{Leuconostoc}

Balcázar et al. (2007) reported that Lc. mesenteroides isolated from rainbow trout intestine inhibited the growth of various pathogens. The same research group supplemented rainbow trout and brown trout diets with Lc. mesenteroides $\left(10^{6} \mathrm{CFU}\right.$ $\mathrm{g}^{-1}$ ) and observed immunomodulation and increased resistance against furunculosis (Balcázar et al., 2007) and A. salmonicida infection (Balcázar et al., 2009). Dietary application of $L c$. mesenteroides CLFP 196 to rainbow trout at $10^{7} \mathrm{CFU} \mathrm{\textrm {g } ^ { - 1 }}$ of feed for 30 days dramatically reduced the mortalities following challenge with L. garvieae (Vendrell et al., 2008). However, Lc. mesenteroides subsp. Mesenteroides, obtained from rainbow trout intestine, failed to improve rainbow trout disease resistance to lactococcosis (Pérez-Sánchez et al., 2011). Although, there are limiting studies over Leuconostoc spp. potential to protect fish against diseases, but available results revealed beneficial effects of Luc. mesenteroides.

\section{Pediococcus}

Huang et al. (2014) isolated $P$. pentosaceus strain 4012 from cobia intestine and observed antagonistic effects on $V$. anguillarum under in vitro condition. Subsequently, dietary administration of $P$. pentosaceus 4012 significantly decreased the cumulative mortality of groupers after $V$. anguillarum infection (Huang et al., 2014). Dietary supplement with probiotic $P$. acidilactici increased resistance of rainbow trout fry against vertebral column compression syndrome (VCCS) (Aubin et al., 2005). Also, combined administration of galactooligosaccharides and $P$. acidilactici for 8 weeks improved the immune parameters and resistance against $S$. iniae in rainbow trout fingerlings. An overview of literature revealed increasing attentions toward administration of $P$. acidilactici as probiotic in aquaculture, 
recently. It seems that this species is capable to be considered as disease protection agent in aquaculture.

\section{Enterococcus}

Chang and Liu (2002) administered a commercial product containing E. faecium SF 68 in European eel, Anguilla anguilla diet and observed lower edwardsiellosis in fish exposed to Edwardsiella tarda. E. gallinarum showed a strong inhibitory effect against $V$. anguillarum in vitro, and under in vivo condition protected sea bass against $V$. anguillarum infection (Sorroza et al., 2013). Recently, Safari et al. (2016) evaluated the benefits of dietary administration of host-derived candidate probiotics E. casseliflavus in juvenile rainbow trout, and results showed that E. casseliflavus could improve growth performance and enhance disease resistance when challenged with $S$. iniae.

\section{Vagococcus}

Sorroza et al. (2012) supplemented sea bass diet with Vagococcus fluvialis $\left(10^{9} \mathrm{cfu}^{-1}\right)$ for 20 days and observed that probiotic fed fish had higher relative percent of survival $(42.3 \%)$ than control group following challenge with $V$. anguillarum. This study showed the potential of Vagococcus spp. and highlighted the needs to additional research in future.

\section{Bacillus sp.}

Bacillus sp. as feed additives improves growth performance and immune response and disease resistance in fish has been extensively reviewed (Mingmongkolchai and Panbangred, 2018). Dietary administration of B. subtilis and B. licheniformis (BioPlus2B) improved trout resistance to infection with Y. ruckeri (Raida et al., 2003). Also, feeding Indian major carp, Labeo rohita with $B$. subtilis at $1.5 \times 10^{7} \mathrm{CFU} \mathrm{g}^{-1}$ increased resistance against $A$. hydrophila infection (Kumar et al., 2006). Newaj-Fyzul et al. (2007) administered different forms (viable, formalized or sonicated cells or cell-free supernatant) of $B$. subtilis $\mathrm{AB} 1$ in rainbow trout diet and observed higher resistance against Aeromonas (Newaj-Fyzul et al., 2007). Furthermore, B. subtilis $\left(8 \times 10^{7} \mathrm{CFU}^{-1}\right)$ reduced mortalities Ictalurus punctatus and striped catfish, Pangasianodon hypophthalmus following challenge with Edwardsiella ictaluri (Ran et al., 2012). Liu et al. (2012) proved that dietary B. subtilis $\left(10^{4}, 10^{6}\right.$, and $10^{8}$ CFU $\mathrm{g}^{-1}$ ) for 14 and 28 days was able to enhance the relative survival percentages of grouper, Epinephelus coioides challenged with Streptococcus sp. A diet supplemented with 0.1 or $0.3 \% B$. subtilis enhanced prophylactic property of red hybrid tilapia, Oreochromis sp. against pathogenic Streptococcus agalactiae (Ng et al., 2014).

Aly et al. (2008b) reported that feeding tilapia with $10^{6}$ and $10^{12}$ cells $\mathrm{g}^{-1}$ B. pumilus enhanced immune and health status and improve resistance against A. hydrophila. B. pumilus has also reported to dramatically improved survival of "Loco" Concholepas concholepas larvae (Leyton et al., 2012). Similarly, Sun et al. (2009) reported that B. pumilus SE5 and B. clausii DE5 obtained from orange-spotted grouper Epinephelus coioides, inhibited growth of pathogenic Staphylococcus aureus, V. harveyi and $V$. parahaemolyticus under in vitro condition. Also, feeding grouper E. coioides larvae with copepod ( $P$. annandalei) enriched
B. clausii DE5 and B. pumilus noticably larval survival (Sun et al., 2013).

Bandyopadhyay and Das Mohapatra (2009) isolated Bacillus circulans PB7 from Catla catla intestine, and subsequently added to Catla catla fingerlings diet at rate of $2 \times 10^{4}, 2 \times 10^{5}$, or $2 \times 10^{6}$ cells per $100 \mathrm{~g}$. After 60 days feeding elevated immune parameters as well as resistance against $A$. hydrophila infection. Likewise, feeding Olive flounder (Paralichthys olivaceus) with (B. subtilis, B. pumilus, and B. licheniformis) at rate of $10^{10} \mathrm{CFU} \mathrm{g}^{-1}$ elevated resistance against $S$. iniae (Cha et al., 2013). Han et al. (2015) stated that feeding with commercial $B$. licheniformis improved the disease resistance against Streptococcus iniae infection in tilapia. Similarly, Nile tilapia fed with $1 \times 10^{6}$ and $1 \times 10^{4} \mathrm{CFU}$ $\mathrm{g}^{-1}$ of B. amyloliquefaciens for 30 days showed higher resistance against pathogenic Yersinia ruckeri or Clostridium perfringens type D (Selim and Reda, 2015). Interestingly, intraperitoneally administration of cellular components (cell wall proteins and whole cell proteins) of Bacillus licheniformis and B. pumilus have been reported to improve immune parameters which per se protected rohu Labeo rohita (Hamilton) against A. hydrophila infection (Ramesh et al., 2015). The overview of literature regarding Bacillus spp. as probiotic aimed at elevation of disease resistance revealed more information on B. subtilis. The extensive research on this species revealed high potential for immunomodulation and disease protection. Indeed, B. subtilis can be considered as beneficial agent for disease bio-control.

\section{Other Gram-Positive Bacteria \\ Clostridium butyricum}

Sakai et al. (1995) demonstrated that dietary C. butyricum increased rainbow trout protection vibriosis. Pan et al. (2008a) stated that C. butyricum CB2 showed strong antagonistic activity to pathogenic A. hydrophila and V. anguillarum. Subsequently, oral administration of live or dead C. butyricum CB2 at dose of $10^{8} \mathrm{CFU} \mathrm{g}{ }^{-1}$ feed enhanced the phagocytic activity of leucocytes and resistance to vibriosis in Chinese drum, Miichthys miiuy (Basilewsky) (Pan et al., 2008b).

\section{Micrococcus}

Dietary application of probiotic Micrococcus luteus increased rainbow trout survival after $A$. salmonicida challenge (Irianto and Austin, 2002). Abd El-Rhman et al. (2009) reported that Nile tilapia fed $M$. luteus containing diets for 6-days per week for 90 days showed decreased mortality following A. hydrophila challenged.

\section{Rhodococcus}

It has reported that the cellular components (cell wall proteins and whole cell proteins) of Rhodococcus SM2 increased rainbow trout protection against $V$. anguillarum (Sharifuzzaman et al., 2011).

\section{Brochothrix}

Dietary administration of Brochothrix thermosphacta BA211 $\left(10^{10}\right.$ cells $\left.\mathrm{g}^{-1}\right)$ protected rainbow trout against skin infections challenged with $A$. bestiarum, i.e., mortalities reduced from 88 to $22 \%$, however, the probiotic had no effect against 
ichthyophthiriasis (caused by the parasite Ichthyophthirius multifiliis) (Pieters et al., 2008).

\section{Kocuria}

Sharifuzzaman and Austin (2010) isolated Kocuria SM1 rainbow trout digestive tract and subsequently added to rainbow trout diet at rate of $10^{8}$ cells $\mathrm{g}^{-1}$. They observed higher protection against challenge with $V$. anguillarum and $V$. ordalii.

\section{Gram-Negative Bacteria Pseudomonas}

Rainbow trout exposed to $P$. fluorescens $\mathrm{AH} 2$ at rate of $10^{5}$ $\mathrm{CFU} / \mathrm{ml}$ for 5 days showed lower mortality after $V$. anguillarum challenge (Gram et al., 1999), while the probiotic did not confer protection of salmon against furunculosis (Gram et al., 2001). P. chlororaphis strain JF3835, obtained from perch (Perca fluviatilis L.) intestine, has ability to control Aeromonas sobria infection in perch (Gobeli et al., 2009). Pseudomonas M162 showed in vitro inhibition to Flavobacterium psychrophilum, and dietary application of M162 increased rainbow trout resistance against F. psychrophilum infection (Korkea-aho et al., 2012). The same research group evaluated protection caused by various strains of Pseudomonas M174 in rainbow trout and observed highest protection against F. psychrophilum caused by M174 strain (Korkea-aho et al., 2011). Giri et al. (2012) fed Labeo rohita with $10^{7}$ and $10^{9} \mathrm{CFU} \mathrm{g}{ }^{-1} \mathrm{P}$. aeruginosa VSG-2 and evaluated fish resistance against $A$. hydrophila. The results revealed that probiotic fed fish had significantly higher resistance against A. hydrophila infection (Giri et al., 2012). Similarly, oral administration of P. aeruginosa PsDAHP1 inhibited biofilm formation and increased defense mechanisms which per se elevated zebrafish protection from $V$. parahaemolyticus DAHV2 infection (Vinoj et al., 2015).

\section{Aeromonas}

Dietary administration of $A$. hydrophila has been reported to reduce mortality caused by $A$. salmonicida in rainbow trout (Irianto and Austin, 2002). Similarly, Irianto et al. (2003) showed that feeding with formalin-inactivated A. hydrophila A351 increased goldfish (Carassius auratus) resistance against A. salmonicida. Likewise, rainbow trout fed A. sobria GC2 at rate of $5 \times 10^{7}$ cells g $^{-1}$ showed improved resistance to L. garvieae and S. iniae (Brunt and Austin, 2005). Also, Pieters et al. (2008) demonstrated that feeding with $10^{8}$ cells $\mathrm{g}^{-1}$ A. sobria GC2 and $10^{10}$ cells $\mathrm{g}^{-1}$ Brochothrix thermosphacta BA211 improved rainbow trout resistance against causal agent of fin rot (i.e., A. bestiarum). Recently, Chi et al. (2014) isolated A. veronii BA-1 from common carp (Cyprinus carpio) intestine. Dietary administration of isolated strain $\left(1 \times 10^{8}\right.$ cell $\left.\mathrm{g}^{-1}\right)$ beneficially affected immune parameters as well as resistance against A. hydrophila in carp.

\section{Shewanella}

Chabrillón et al. (2006) fed gilthead seabream (Sparus aurata) with S. putrefaciens (Pdp11) at rate of $10^{8} \mathrm{CFU} \mathrm{g} \mathrm{g}^{-1}$ and then challenged with V. anguillarum DC11R2a. The results revealed significantly lower mortality in probiotic fed fish (10\%) compared to control group (56\%). In a study with Senegalese sole (Solea senegalensis), Diaz-Rosales et al. (2009) evaluated probiotic potential of S. putrefaciens Pdp11 and S. baltica Pdp13. They observed elevated immune responses as well as resistance against Photobacterium damselae sub sp. Piscicida. Also, De la Banda et al. (2012) evaluated effectiveness of different forms (fresh and lyophilized cells) of S. putrefaciens Pdp11, in juvenile Senegalese sole diet and observed improved growth and protection against $P$. damselae subsp. piscicida. Recently, the same group reported that dietary S. putrefaciens Pdp11 modulated immune related genes expression, intestinal microbiota as well as intestinal conditions which per se improved stress tolerance caused by crowding condition. (Tapia-Paniagua et al., 2014). Dietary application of $1 \times 10^{8}$ cell g$^{-1}$ S. xiamenensis A-1 and S. xiamenensis A-2, which isolated from grass carp (Ctenopharyngodon idellus) intestine, for 28 days decrease the survival of grass carp after experimentally challenged with A. hydrophila (Wu et al., 2015).

\section{Enterobacter}

Capkin and Altinok (2006) isolated E. cloacae from rainbow digestive tract and supplemented trout diet with isolated strain at rate of $10^{8} \mathrm{CFU} \mathrm{g}^{-1}$. Interestingly, following challenge with Yersinia ruckeri, probiotic fed fish showed significantly higher survival (99.2\%) compared those fed control diet (35\%). Probiotic strains C6-6 and C6-8 which supposed to be E. amnigenus and Enterobacter sp., inhibited F. psychrophilum (Burbank et al., 2011). Moreover, supplementation of rainbow trout with $10^{6}$ to $10^{8}$ cells $\mathrm{g}^{-1}$ of those probiotic resulted in higher resistance to Flavobacterium psychrophilum infection (Burbank et al., 2011). Also, inclusion of inactivated E. faecalis in rainbow trout diet at rate of $5 \mathrm{~g} \mathrm{~kg}^{-1}$ decreased mortality caused by experimental A. salmonicida infection (Rodríguez-Estrada et al., 2013).

\section{Roseobacter}

It has been reported that rotifers enriched with Roseobacter 274 increased turbot, Scophthalmus maximus L., larvae protection against $V$. anguillarum infection (Planas et al., 2006). An isolate from seawater in scallop (Pecten maximus) identified as Phaeobacter (Roseobacter) gallaeciensis BS107 (DSM17395), which antagonized fish pathogenic bacteria in vitro and reduced the mortality by approximately $10 \%$ in cod larvae upon challenge with $V$. anguillarum (D'Alvise et al., 2012). Treatment of Turbot (Scophthalmus maximus) larvae with $10^{7} \mathrm{CFU} \mathrm{mL}^{-1}$ Roseobacter sp. strain 27-4, decreased cumulative mortality following challenge with V. anguillarum (Hjelm et al., 2004). Likewise, feeding turbot larvae with Roseobacter sp. strain 274 enriched rotifers improved protection against V. anguillarum, (Planas et al., 2006).

\section{Vibrio}

Vibrio alginolyticus showed in vitro inhibition to $V$. ordalii, $V$. anguillarum, A. salmonicida and $Y$. ruckeri, and in vivo protection to Atlantic salmon challenged with A. salmonicida (Austin et al., 1995). Dietary administration of V. fluvialis 
resulted in higher survival in rainbow trout challenged with A. salmonicida (Irianto and Austin, 2002).

\section{Zooshikella}

Kim et al. (2010) showed that different levels $\left(3.4 \times 10^{4}, 3.5 \times 10^{6}\right.$ and $3.4 \times 10^{8} \mathrm{CFU} \mathrm{g}^{-1}$ ) of dietary Zooshikella sp. JE-34 helps to improve the innate immune response and control streptococcus inane infections in olive flounder (Paralichthys olivaceus).

\section{Flavobacterium}

Chi et al. (2014) supplemented carp diet with Flavobacterium sasangense BA-3 $\left(1 \times 10^{8}\right.$ cell g $\left.^{-1}\right)$ isolated from the common carp intestine for 28 days. They observed enhanced immune parameters as well as resistance against A. hydrophila infection.

\section{Yeast}

The potential of yeast as probiotic to improve disease resistance has been demonstrated in several studies. Abdel-Tawwab et al. (2008) reported that diets supplemented with baker's yeast S. cerevisiae at dose of $0.25,0.50,1.0,2.0$, or $5.0 \mathrm{~g}$ yeast $/ \mathrm{kg}$ reduced mortality in tilapia after intraperitoneal injection pathogenic A. hydrophila. Subsequently, the same group observed that Baker's yeast improves the resistance against the water-borne $\mathrm{Cu}$ toxicity in Galilee tilapia Sarotherodon galilaeus (L.) (AbdelTawwab et al., 2010). Quentel et al. (2005) reported that singular or combined administration of $P$. acidilactici and S. cerevisiae var. boulardii improved rainbow trout resistance against Y. ruckeri. Reyes-Becerril et al. (2011) supplemented Leopard grouper (Mycteroperca rosacea) diet with Debaryomyces hansenii CBS $8339\left(10^{6} \mathrm{CFU} \mathrm{g}^{-1}\right)$ for 5 weeks. At the end of feeding trial, probiotic fed fish ad noticeably higher immunoglobulin $\mathrm{M}$ (IgM) level, catalase (CAT) and superoxide dismutase (SOD) activities following A. hydrophila AH-315 challenge. Generally, the majority of studies performed on yeasts revealed beneficial effects on immune system (Hai, 2015). Hence, it seems that they can be considered as beneficial means of disease control and control.

\section{PROBIOTICS AND BACTERIAL DISEASES IN SHELLFISH (TABLE 2) \\ Gram-Positive Bacteria Lactic Acid Bacteria}

Ajitha et al. (2004) supplemented Indian white shrimp (Penaeus indicus) diet with as single dose $\left(5 \times 10^{6} \mathrm{CFU} \mathrm{g}^{-1}\right)$ of different probiotics including $L b$. acidophilus, S. cremoris, Lb. bulgaricus 56 or L. bulgaricus57 at doses of for 4 weeks and at the end of feeding trial shrimp exposed to experimental Vibrio alginolyticus infection. The results revealed substantially higher resistance (56-72\%) compared control group (20\%) (Ajitha et al., 2004). Also, dietary supplemented with $10^{10} \mathrm{CFU} \mathrm{kg}^{-1}$ of $\mathrm{Lb}$. plantarum upregulated proPO and $\mathrm{PE}$ genes, enhanced $\mathrm{PO}$ and SOD activities as well as resistance against $V$. alginolyticus in white shrimp (Chiu et al., 2007). Similarly, Vieira et al. (2010) reported that diet supplemented with probiotic $L b$. plantarum modulated intestinal microbiota as well as resistance against $V$. harveyi. In addition, a Lactobacillus sp. has been reported to improve survival by $72 \%$ and performance of pearl oyster, $P$. mazatlanica (Aguilar-Macias et al., 2010). Furthermore, in a study with juvenile tiger shrimp (Penaeus monodon) Lb. acidophilus $04\left(10^{5}\right.$ CFU g ${ }^{-1}$ ) was administered for 1 month and increased resistance (80\% survival) was observed following exposure with pathogenic V. alginolyticus (Sivakumar et al., 2012). Interestingly, Dash et al. (2015) administered heat-killed form of $L b$. plantarum at rate of $10^{8} \mathrm{CFU} \mathrm{g}^{-1}$ in $M$. rosenbergii diet for 90 days. While no significant effects were observed on growth performance, feeding on probiotic supplemented diet noticeably enhanced immune responses and disease resistance.

Swain et al. (2009) reported that feeding with E. faecium MC13 and Lactococcus garvieae B49 protected post larval shrimp, P. monodon, against challenge with $V$. harveyi and $V$. parahaemolyticus. Similarly, feeding blue shrimp (Litopenaeus stylirostris) with probiotic $P$. acidilactici enhanced protection against $V$. nigripulchritudo SFn1; the mortality in probiotic and control group were 25 and $41.7 \%$, respectively (Castex et al., 2010). Dietary administration of $L b$. pentosus HC-2 and E. faecium NRW-2 noticeably enhanced resistance against pathogenic V. parahaemolyticus ATCC 17802 in L. vannamei (Sha et al., 2016).

\section{Bacillus}

To study protective effects of Bacillus subtilis BT23, Vaseeharan and Ramasamy (2003) treated black tiger shrimp with $10^{6}-10^{8}$ CFU $\mathrm{ml}^{-1}$ probiotic for 6 days and then challenged with $V$. harveyi. The results revealed significantly lower mortality in treated groups (Vaseeharan and Ramasamy, 2003). Similarly, Balcázar et al. (2007) fed L. vannamei juvenile with B. subtilis for 28 days and then exposed to pathogenic $V$. harveyi for $24 \mathrm{~h}$. The results revealed substantially lower mortality in treated group (18.25\%) compared to those in control (51.75\%) in the control group (Balcázar et al., 2007). Also, Zokaeifar et al. (2012) tested combined administration of two probiotic strains (B. subtilis L10 and G1) in juvenile white shrimp. Shrimps were fed with two levels of $10^{5}$ and $10^{8} \mathrm{CFU} \mathrm{g} \mathrm{g}^{-1}$ of selected probiotics for 8 weeks. At the end of feeding trial elevated growth performance, digestive enzyme activity, upregulated immune related genes as well as resistance against $V$. harveyi were observed (Zokaeifar et al., 2012). Liu et al. (2014) reported that dietary administration of B. subtilis strain S12 (isolated from L. vannamei digestive tract), beside in vitro antagonistic activity against aquatic animal pathogens, improved resistance against $V$. harveyi infection (Liu et al., 2014).

Rengpipat et al. (1998) reported that supplementation of black tiger shrimp with different forms (i.e., of fresh cells, fresh cells in normal saline solution and a lyophilized form) of Bacillus S11 for 100 days resulted in significantly higher growth performance and survival. Also, the authorsperformed experimental challenge $V$. harveyi at the end of feeding trial and surprisingly observed no mortality in probiotic fed shrimps, while survival rate was just $26 \%$ in control group (Rengpipat et al., 1998). Subsequently, the same research group studied possible effects of Bacillus S11 and concluded limited improvement in resistance against $V$. harveyi (Rengpipat et al., 2003). In another routes of administration, Luis-Villaseñor 
TABLE 2 | Overview of the effects of probiotics against pathogenic bacteria in shellfish.

\begin{tabular}{|c|c|c|c|c|}
\hline Probiotic & Pathogen or disease & Shellfish species & Beneficial effects & Reference \\
\hline \multicolumn{5}{|c|}{ GRAM-POSITIVE BACTERIA } \\
\hline $\begin{array}{l}\text { Lactobacillus acidophilus } \\
\text { Streptococcus cremoris } \\
\text { Lactobacillus bulgaricus }\end{array}$ & Vibrio alginolyticus & $\begin{array}{l}\text { Indian white shrimp (Penaeus } \\
\text { indicus) }\end{array}$ & Higher survival rate & Ajitha et al., 2004 \\
\hline \multirow[t]{2}{*}{ Lactobacillus plantarum } & Vibrio alginolyticus & $\begin{array}{l}\text { White shrimp (Litopenaeus } \\
\text { vannamei) }\end{array}$ & $\begin{array}{l}\text { Increased clearance efficiency to } V \text {. } \\
\text { alginolyticus and the survival rate }\end{array}$ & Chiu et al., 2007 \\
\hline & Vibrio harveyi & $\begin{array}{l}\text { White shrimp (Litopenaeus } \\
\text { vannamei) }\end{array}$ & Enhanced disease resistance & Vieira et al., 2010 \\
\hline Lactobacillus acidophilus & Vibrio alginolyticus & Shrimp (Penaeus monodon) & Higher survival ratio & Sivakumar et al., 2012 \\
\hline $\begin{array}{l}\text { Enterococcus faecium } \\
\text { Lactococcus garvieae }\end{array}$ & $\begin{array}{l}\text { Vibrio harveyi and Vibrio } \\
\text { parahaemolyticus }\end{array}$ & Shrimp (Penaeus monodon) & Enhanced disease resistance & Swain et al., 2009 \\
\hline Pediococcus acidilactici & Vibrio nigripulchritudo & $\begin{array}{l}\text { Blue shrimp (Litopenaeus } \\
\text { stylirostris) }\end{array}$ & Higher survival rate & Castex et al., 2010 \\
\hline $\begin{array}{l}\text { Lactobacillus pentosus } \\
\text { Enterococcus faecium }\end{array}$ & Vibrio parahaemolyticus & Shrimp (Litopenaeus vannamei) & Enhanced the survival rate & Sha et al., 2016 \\
\hline \multirow[t]{2}{*}{ Bacillus subtilis } & Vibrio harveyi & Shrimp (Penaeus monodon) & Enhanced the survival rate & $\begin{array}{l}\text { Vaseeharan and } \\
\text { Ramasamy, } 2003\end{array}$ \\
\hline & Vibrio harveyi & Shrimp (Litopenaeus vannamei) & Enhanced the survival rate & $\begin{array}{l}\text { Balcázar et al., 2007; } \\
\text { Zokaeifar et al., 2012; Liu } \\
\text { et al., } 2014\end{array}$ \\
\hline Bacillus sp. & Vibrio harveyi & Shrimp (Penaeus monodon) & Enhanced the survival rate & Rengpipat et al., 1998 \\
\hline Streptococcus phocae & Vibrio harveyi & Shrimp (Penaeus monodon) & Enhanced the survival rate & Swain et al., 2009 \\
\hline Arthrobacter sp. & Vibrio parahaemolyticus & Shrimp (Litopenaeus vannamei) & $\begin{array}{l}\text { Significantly enhanced the immune } \\
\text { parameters and significantly } \\
\text { decreased mortalities }\end{array}$ & Li et al., 2008 \\
\hline \multicolumn{5}{|c|}{ GRAM-NEGATIVE BACTERIA } \\
\hline Streptomyces sp. & Vibrio harveyi & $\begin{array}{l}\text { Black tiger shrimp (Penaeus } \\
\text { monodon) }\end{array}$ & $\begin{array}{l}\text { Better survival and growth } \\
\text { performance }\end{array}$ & Das et al., 2010 \\
\hline Pseudomonas aeruginosa & Vibrio harveyi & $\begin{array}{l}\text { Western king prawns (Penaeus } \\
\text { latisulcatus) }\end{array}$ & Improved the survival rate & Van Hai et al., 2009 \\
\hline Pseudomonas sp. & Vibrio harveyi & Whrimp (Penaeus monodon) & Improved the survival rate & Pai et al., 2010 \\
\hline \multirow[t]{3}{*}{$\begin{array}{l}\text { Alteromonas macleodii } \\
\text { Neptunomonas sp. }\end{array}$} & Vibrio splendidus & $\begin{array}{l}\text { Greenshell mussel(Perna } \\
\text { canaliculus) }\end{array}$ & $\begin{array}{l}\text { Improved survival and suppress } \\
\text { naturally occurring vibrios }\end{array}$ & $\begin{array}{l}\text { Kesarcodi-Watson et al., } \\
2010\end{array}$ \\
\hline & $\begin{array}{l}\text { Vibrio coralliilyticus and } \\
\text { V. splendidus }\end{array}$ & Scallop (Pecten maximus & Improved the survival rate & $\begin{array}{l}\text { Kesarcodi-Watson et al., } \\
2012\end{array}$ \\
\hline & $\begin{array}{l}\text { Vibrio coralliilyticus and } \\
\text { Vibrio pectenicida }\end{array}$ & Flat oyster (Ostrea edulis) & Improved the survival rate & $\begin{array}{l}\text { Kesarcodi-Watson et al., } \\
2012\end{array}$ \\
\hline $\begin{array}{l}\text { Phaeobacter gallaeciensis, } \\
\text { Pseudoalteromonas }\end{array}$ & $\begin{array}{l}\text { Vibrio coralliilyticus and } \\
\text { V. splendidus }\end{array}$ & Scallop (Pecten maximus) & Improved the survival rate & $\begin{array}{l}\text { Kesarcodi-Watson et al., } \\
2012\end{array}$ \\
\hline \multicolumn{5}{|l|}{ YEAST } \\
\hline $\begin{array}{l}\text { Phaffia rhodozyma } \\
\text { Saccharomyces cerevisiae }\end{array}$ & vibriosis & Shrimp (Litopenaeus vannamei) & Improve resistance against vibriosis & Scholz et al., 1999 \\
\hline
\end{tabular}

et al. (2011) isolated four Bacillus strains from white shrimp digestive tract and added to white shrimp culture water at

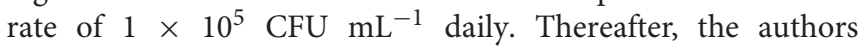
observed elevated overall survival of L. vannamei larvae (LuisVillaseñor et al., 2011). In another study with post larvae, Ravi et al. (2007) claimed elevated resistance against $V$. harveyi following treatment of post larvae with Paenibacillus sp. EF012164 and Bacillus cereus DQ915582 (Ravi et al., 2007). The same results were also reported in case of Bacillus sp. P11 which resulted in substantially higher survival in comparison with control group (0\%) following experimental challenge with $V$. harveyi (Utiswannakul et al., 2011). The literature review denote that, perhaps, the most studied and effective probiont in shrimp culture is $B$. subtilis. This species showed positive effects on shrimp resistance to various pathogens. Hence, can be considered as a means of disease control and control in shrimp aquaculture.

\section{Other Gram-Positive Bacteria}

Swain et al. (2009) demonstrated that feeding P. monodon post larvae with Streptococcus phocae P180 significantly improved growth performance as well as protection against $V$. harveyi. However, the probiotic failed to protect the animals against $V$. parahaemolyticus (Swain et al., 2009). The probiotic Arthrobacter 
XE-7 was administered orally at four different doses of $0,10^{6}$, $10^{8}$, and $10^{10} \mathrm{CFU} \mathrm{g}{ }^{-1}$ feed for 63 days in Pacific white shrimp, L. vannamei. Li et al. (2008) supplemented shrimp diet with Arthrobacter XE-7 and observed beneficial effects on intestinal microbiota, immune response as well as resistance against $V$. parahaemolyticus (Li et al., 2008).

\section{Gram-Negative Bacteria \\ Vibrio}

Thompson et al. (2010) demonstrate in vitro growth inhibition of shrimp pathogens by probiotic $V$. gazogenes NCIMB 2250. Also, the same author revealed that feeding white shrimp with dietary V. gazogenes NCIMB 2250 elevated performance and health status as well as decreased of Vibrio sp. count in intestinal microbiota (Thompson et al., 2010). Likewise, Vibrio NE17 isolated from the egg samples improved performance as well as immune parameters of freshwater prawn, Macrobrachium rosenbergii (Mujeeb Rahiman et al., 2010). Also, a abalone, $H$. rufescens revealed that combined administration of three probiotics (Vibrio sp. C21-UMA, Agarivorans albus F1-UMA and Vibrio sp. F15-UMA) using macroalgae M. integrifolia as vector increased significantly the survival of, in a period of 210 days (Silva-Aciares et al., 2011).

\section{Streptomyces}

In 2016, Tan et al. (2016) have reviewed the use of the genus Streptomyces bacteria as a probiotic in controlling diseases and improving the health and quality of aquaculture production. Das et al. (2010) used Marine Streptomyces strains (CLS-28, CLS-39) in Artemia culture and concluded that this probiotic significantly increased resistance of Artemia nauplii and adult against $V$. harveyi and $V$. proteolyticus (Das et al., 2010). Thereafter, they supplemented black tiger shrimp post larvae diet with $1 \%$ Streptomyces for 15 days. The results revealed improved resistance against $V$. harveyi and growth performance in probiotic fed shrimps (Das et al., 2010).

\section{Pseudomonas}

Van Hai et al. (2009) supplemented western king prawns (Penaeus latisulcatus) diet with a single dose $\left(20 \times 10^{5} \mathrm{CFU}\right.$ $\mathrm{kg}^{-1}$ ) of P. aeruginosa and P. synxantha for 84 days and reported higher survival rate in P.aeruginosa fed group. Also, combined administration of those probiotic was more effective than singular. Pai et al. (2010) reported in vitro inhibition of V. harveyi MCCB 111 growth by Pseudomonas MCCB 102 and $\mathrm{MCCB}$ 103. Also, in vivo study revealed noticeable increase of tiger shrimp larvae survival against V. harveyi MCCB 111.

\section{Alteromonas}

Alteromonas macleodii 0444 has been reported to control of Vibrio splendidus infection in Greenshell mussel, Perna canaliculus, which per se caused increase in survival rate and natural Vibrios in the culture environment (Kesarcodi-Watson et al., 2010). Also, the same research group showed that $A$. macleodii 0444 protected scallop (Pecten maximus) and flat oyster (Ostrea edulis) larvae against $V$. coralliilyticus and V. splendidus, $V$. pectenicida infections (Kesarcodi-Watson et al., 2012).

\section{Neptunomonas}

Kesarcodi-Watson et al. (2010) demonstrated that Neptunomonas 0536 was capable of controlling infection caused by $V$. splendidus in Greenshell mussel ( $P$. canaliculus). Also, the same research group highlighted the potential of this probiotic to protect scallop and flat oyster from larvae against $V$. coralliilyticus, $V$. splendidus and $V$. pectenicida (Kesarcodi-Watson et al., 2010, 2012).

\section{Phaeobacter}

Phaeobacter gallaeciensis protected scallop larvae against $V$. coralliilyticus and V. splendidus. Also, the same probiotic strain protected flat oyster larvae against $V$. coralliilyticus and $V$. pectenicida, and Pacific oyster larvae against $V$. coralliilyticus but not $V$. pectenicida (Kesarcodi-Watson et al., 2012).

\section{Pseudoalteromonas}

Kesarcodi-Watson et al. (2012) reported that Pseudoalteromonas D41 as probiotic increased resistance of scallop larvae and Pacific oysters against $V$. splendidus and V. coralliilyticus, respectively.

\section{Yeast}

To the best of our knowledge there is limited information regarding application of yeasts as probiotic in shellfish aquaculture. In an early study Scholz et al. (1999) supplemented white shrimp with $1 \%$ Phaffia rhodozyma and S. cerevisiae and reported elevation of protection against vibriosis. Furthermore, feeding pearl oyster, $P$. mazatlanica with marine yeast (Yarrowia lipolytica) enriched microalgae resulted in enhanced growth and survival (Aguilar-Macias et al., 2010).

\section{PROBIOTICS AND VIRAL DISEASES IN FISH}

The occurrence of viral diseases causes mass mortality in aquaculture practice and considering still there is limited effective vaccine this could a bottleneck for aquaculture industry which resulted in substantial economic loss. In this regard, the potential of probiotics to be used as a means of controlling viral disease has been shown in few studies. For instance, Balcázar et al. (2007) in an in vitro study demonstrated antiviral activity of probiotic strains (including Vibrios spp., Pseudomonas spp., Aeromonas spp.) against infectious hematopoietic necrosis virus (IHNV). Likewise, Maeda et al. (1997) reported that Pseudoalteromonas undina, VKM-124 improved larval survival by giving the larvae a protection against Sima-aji Neuro Necrosis Virus (SJNNV) when added to Yellow Jack (Carangoides bartholomaei) larval tanks. Harikrishnan et al. (2010) studied antiviral activity of dietary two commercial probiotics (Lactobacil and/or Sporolac) in Olive flounder. The results revealed that both probiotics increased fish resistance against lymphocystis disease virus (LCDV) infection (Harikrishnan et al., 2010). The possible control of iridovirus in grouper (Epinephelus coioides) through dietary administration of probiotics (Lb. plantarum) was studied by Son et al. (2009). The results revealed higher survival in probiotic fed fish compared control group. In another study Liu et al. (2012) tested possible protection of grouper against iridovirus using dietary B. subtilis 
E20 and observed 50\% higher survival than those in nonprobiotic group. Likewise, dietary S. cerevisiae at rate of $5.3 \times 10^{7}$ $\mathrm{CFU} \mathrm{kg} \mathrm{kg}^{-1}$ protected grouper against iridovirus (GIV) infection (Chiu et al., 2010). Indeed, while fish fed control diet had $16.7 \%$ survival, probiotic fed fish survival was $43.3 \%$. Although there are extensive literature regarding immunomodulatory effects of probiotics, they are not enough to speculate potential antiviral effects of probiotics. Therefore, more studies should be conducted to illustrate the effect of probiotics on the viral diseases of fish and possible mechanisms.

\section{PROBIOTICS AND VIRAL DISEASES IN SHELLFISH}

Unlike fish, shrimp aquaculture suffers from substantial economical loses due to occurrence and spread of different viral diseases like white spot syndrome virus (WSSV), lymphocystis disease virus (LCDV), infectious hypodermal and hematopoietic necrosis virus (IHHNV) etc. Treatment of shrimp culture environment or feed with probiotics has been suggested as efficient means of prevention and controlling viral diseases (Lakshmi et al., 2013). For instance, Vibrio spp. obtained from tiger shrimp hatchery showed strong antagonistic activity against IHNV and Oncorhynchus masou virus (OMV) (Direkbusarakom et al., 1998). The majority of studies practiced dietary administration of probiotics and tested anti-viral effect in different shrimp species. Rodríguez et al. (2007) stated

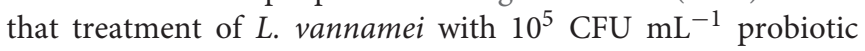
$V$. alginolyticus significantly increased resistance against WSSV compared to non-treated shrimps. Moreover, dietary administration of $10^{10} \mathrm{CFU} \mathrm{g}^{-1} \mathrm{~B}$. megaterium has resulted in higher survival and increased protection against WSSV (Li et al., 2009). Also, Leyva-Madrigal et al. (2011) reported that feeding white shrimp with either $P$. pentosaceus or Staphylococcus hemolyticus decrease WSSV infection. On the contrary, dietary supplemented with $10^{5} \mathrm{CFU} \mathrm{g}^{-1}$ of a mixture lactic acid bacteria (BAL3, BAL7, BC1, and CIB1) had no significant effects on $L$. vannamei resistance against WSSV infections (Partida-Arangure et al., 2013). Recently, Chai et al. (2016) isolated Bacillus PC465 from Fenneropenaeus chinensis gut and evaluated its anti-viral effects via dietary administration. The results showed the application of Bacillus PC465 enhances the gut microbial structures, promotes the immune status of shrimp which per se protected against WSSV. Despite the needs for additional research to explain mechanisms, some researchers proposed immunomodulatory nature of probiotics as an important factor in observed protection against WSSV (Merrifield et al., 2010b).

\section{PROBIOTICS AND PARASITIC DISEASES IN FISH AND SHELLFISH}

In general, available information about the probiotic control parasite diseases in fish and shellfish was limited. Dietary administration of Aeromonas sobria GC2 BA211 for 14 days at rate of $10^{8}$ and $10^{10}$ cells $\mathrm{g}^{-1}$, respectively, protected rainbow trout against Ichthyophthirius multifiliis parasite and reduced the mortalities from 98 to $0 \%$. On the other hand, Brochothrix thermosphacta at dose of $10^{10}$ cells $\mathrm{g}^{-1}$ of feed failed to protect rainbow trout against the skin parasite (Pieters et al., 2008). Atira et al. (2012) assessed the inhibition of the growth of the parasitic Saprolegnia parasitica A3 on catfish (Pangasius hypophthalamus) using Lactobacillus plantarum FNCC 226 under in vivo and in vitro conditions. They concluded the potential of L. plantarum for inhibiting $S$. parasitica and therefore suggested as an environment-friendly means of parasite control in catfish aquaculture.

\section{CONCLUDING REMARKS AND FURTHER PERSPECTIVES}

The review of available literature revealed the promising effects of probiotics on disease resistance of fish and shellfish. Therefore, it can be speculated that this environment friendly dietary supplement will receive increasing attention as an alternative for antibiotic in aquaculture. However, this fact should be kept mind that the results of previous researches revealed that the effects of probiotics are species specific. Therefore, optimum probiont, administration dose and dulactobacilli were among the most studied probiotics in shrimps. The studies reviewed here revealed the potential of lactobacilli to help in resolving the issue of diseases in shrimp culture. Given the primary nature of shrimp immune system as well as sensitivity to disease outbreak, development of such effective, environment-friendly means of disease bio-control is of high importance. The results of the mentioned above studies encourage further studies regarding bio-control of parasite in aquaculture using probiotics. However, the exact mode of actions remained to be clarified. Furthermore, despite promising effects obtained regarding probiotics as biocontrol against viral and parasitic disease in aquatic animals, there is very limited research available compared with other immunostimulants. Consequently, extensive research should be performed regarding determination of antiviral nature of known probiotics. The last but not the least, present understanding on modes of action of probiotics effects on immune system is very limited and merit further research, especially the molecular mechanisms of the interactions between the probiotic and host.

\section{AUTHOR CONTRIBUTIONS}

$\mathrm{SH}$ and $\mathrm{ZZ}$ drafted the manuscript. Y-ZS performed the literature collection. AW participated in this review. All authors performed the critical revision of the article and approved the final version for publication. 


\section{REFERENCES}

Abd El-Rhman, A. M., Khattab, Y. A. E., and Shalaby, A. M. E., (2009). Micrococcus luteus and Pseudomonas species as probiotics for promoting the growth performance and health of Nile tilapia, Oreochromis niloticus. Fish Shellfish Immun. 27, 175-180. doi: 10.1016/j.fsi.2009.03.020

Abdel-Tawwab, M., Abdel-Rahman, A. M., and Ismael, N. E. M., (2008). Evaluation of commercial live bakers' yeast, Saccharomyces cerevisiae as a growth and immunity promoter for fry nile tilapia, Oreochromis niloticus (L.) challenged in situ with Aeromonas hydrophila. Aquaculture 280, 185-189. doi: 10.1016/j.aquaculture.2008.03.055

Abdel-Tawwab, M., Mousa, M. A. A., and Mohammed, M. A., (2010). Use of live baker's yeast, Saccharomyces cerevisiae, in practical diet to enhance the growth performance of Galilee tilapia, Sarotherodon galilaeus (L.), and its resistance to environmental copper toxicity. J. World Aquacult. Soc. 41, 214-223. doi: 10.1111/j.1749-7345.2010.00361.x

Aguilar-Macias, O. L., Ojeda-Ramirez, J. J., Campa-Cordova, A. I., and Saucedo, P. E. (2010). Evaluation of natural and commercial probiotics for improving growth and survival of the pearl oyster, Pinctada mazatlanica, during late hatchery and early field culturing. J. World Aquacult. Soc. 41, 447-454. doi: $10.1111 / j .1749-7345.2010 .00386 . x$

Ajitha, S., Sridhar, M., Sridhar, N., Singh, I. S. B., and Varghese, V., (2004). Probiotic effects of lactic acid bacteria against Vibrio alginolyticus in Penaeus (Fenneropenaeus indicus). Asian Fish. Sci. 17, 71-80.

Al-Dohail, M. A., Hashim, R., and Aliyu-Paiko, M., (2011). Evaluating the use of Lactobacillus acidophilus as a biocontrol agent against common pathogenic bacteria and the effects on the haematology parameters and histopathology in African catfish Clarias gariepinus juveniles. Aquac. Res. 42, 196-209. doi: 10.1111/j.1365-2109.2010.02606.x

Aly, S. M., Ahmed, Y. A. G., Ghareeb, A. A. -A., and Mohamed, M. F., (2008a). Studies on Bacillus subtilis and Lactobacillus acidophilus, as potential probiotics, on the immune response and resistance of Tilapia nilotica (Oreochromis niloticus) to challenge infections. Fish Shellfish Immun. 25, 128-136. doi: 10.1016/j.fsi.2008.03.013

Aly, S. M., Mohamed, M. F., and John, G. (2008b). Effect of probiotics on the survival, growth and challenge infection in Tilapia nilotica (Oreochromis niloticus). Aquac. Res. 39, 647-656. doi: 10.1111/j.1365-2109.2008. 01932.x

Antony, S. P., Singh, I. B., Jose, R. M., Kumar, P. A., and Philip, R., (2011). Antimicrobial peptide gene expression in tiger shrimp, Penaeus monodon in response to gram-positive bacterial probionts and white spot virus challenge. Aquaculture 316, 6-12. doi: 10.1016/j.aquaculture.2011. 03.025

Arellano-Carbajal, F., and Olmos-Soto, J. (2002). Thermostable $\alpha-1,4$-and $\alpha-1$, 6-glucosidase enzymes from Bacillus sp. isolated from a marine environment. World. J. Microb. Biot. 18, 791-795. doi: 10.1023/A:10204332 10432

Atira, N. J., Aryantha, I. N. P., and Kadek, I. D. G. (2012). The curative action of Lactobacillus plantarum FNCC 226 to Saprolegnia parasitica A3 on catfish (Pangasius hypophthalamus, Sauvage). Int. Food Res. J. 19, 1723-1727.

Aubin, J., Gatesoupe, F. J., Labbé, L., and Lebrun, L. (2005). Trial of probiotics to prevent the vertebral column compression syndrome in rainbow trout (Oncorhynchus mykiss Walbaum). Aquac. Res. 36, 758-767. doi: 10.1111/j.1365-2109.2005.01280.x

Austin, B., Stuckey, L. F., Robertson, P. A. W., Effendi, I., and Griffith, D. R. W. (1995). A probiotic strain of Vibrio alginolyticus effective in reducing diseases caused by Aeromonas salmonicida, Vibrio anguillarum and Vibrio ordalii. J. Fish. Dis. 18, 93-96. doi: 10.1111/j.1365-2761.1995.tb01271.x

Azimirad, M., Meshkini, S., Ahmadifard, N., and Hoseinifar, S. H. (2016). The effects of feeding with synbiotic (Pediococcus acidilactici and fructooligosaccharide) enriched adult Artemia on skin mucus immune responses, stress resistance, intestinal microbiota and performance of angelfish (Pterophyllum scalare). Fish Shellfish Immun. 54, 516-522. doi: $10.1016 /$ j.fsi.2016.05.001

Balcázar, J. L., De Blas, I., Ruiz-Zarzuela, I., Cunningham, D., Vendrell, D., and Múzquiz, J. L. (2006). The role of probiotics in aquaculture. Vet. Microbiol. 114, 173-186. doi: 10.1016/j.vetmic.2006.01.009
Balcázar, J. L., De Blas, I., Ruiz-Zarzuela, I., Vendrell, D., Gironés, O., and Muzquiz, J. L. (2007). Enhancement of the immune response and protection induced by probiotic lactic acid bacteria against furunculosis in rainbow trout (Oncorhynchus mykiss). FEMS Immunol. Med. Mic. 51, 185-193. doi: 10.1111/j.1574-695X.2007.00294.x

Balcázar, J. L., Vendrell, D., De Blas, I., Ruiz-Zarzuela, I., and Múzquiz, J. L. (2009). Effect of Lactococcus lactis CLFP 100 and Leuconostoc mesenteroides CLFP 196 on Aeromonas salmonicida infection in brown trout (Salmo trutta). J. Mol. Microb. Biotech. 17, 153-157. doi: 10.1159/000226588

Bandyopadhyay, P., and Das Mohapatra, P. K. (2009). Effect of a probiotic bacterium Bacillus circulans PB7 in the formulated diets: on growth, nutritional quality and immunity of Catla catla (Ham.). Fish Physiol. Biochem. 35, 467-478. doi: 10.1007/s10695-008-9272-8

Beck, B. R., Kim, D., Jeon, J., Lee, S. M., Kim, H. K., Kim, O. J., et al. (2015). The effects of combined dietary probiotics Lactococcus lactis BFE920 and Lactobacillus plantarum FGL0001 on innate immunity and disease resistance in olive flounder (Paralichthys olivaceus). Fish Shellfish Immun. 42, 177-183. doi: 10.1016/j.fsi.2014.10.035

Bron, P. A., Tomita, S., van Swam, I. I., Remus, D. M., Meijerink, M., Wels, M., et al. (2012). Lactobacillus plantarum possesses the capability for wall teichoic acid backbone alditol switching. Microb. Cell. Fact. 11:123. doi: 10.1186/1475-2859-11-123

Brunt, J., and Austin, B. (2005). Use of a probiotic to control lactococcosis and streptococcosis in rainbow trout, Oncorhynchus mykiss (Walbaum). J. Fish. Dis. 28, 693-701. doi: 10.1111/j.1365-2761.2005.00672.x

Burbank, D. R., Shah, D. H., LaPatra, S. E., Fornshell, G., and Cain, K. D. (2011). Enhanced resistance to coldwater disease following feeding of probiotic bacterial strains to rainbow trout (Oncorhynchus mykiss). Aquaculture 321, 185-190. doi: 10.1016/j.aquaculture.2011.09.004

Capkin, E., and Altinok, I. (2006). Effects of dietary probiotic suplementations on prevention/treatment of Yersiniosis disease. J. Appl. Microbiol. 106, 1147-1153. doi: 10.1111/j.1365-2672.2008.04080.x

Castex, M., Lemaire, P., Wabete, N., and Chim, L. (2010). Effect of probiotic Pediococcus acidilactici on antioxidant defences and oxidative strees of Litopenaeus stylostris under Vibrio nigripulchritudo challenge. Fish Shellfish Immun. 28, 622-631. doi: 10.1016/j.fsi.2009.12.024

Cha, J. H., Rahimnejad, S., Yang, S. Y., Kim, K. W., and Lee, K. J. (2013). Evalutations of Bacillus spp. as dietary additives on growth performance, innate immunity and disease resistance of olive flounder (Paralichthys olivaceus) against Streptococcus iniae and as water additives. Aquaculture 402, 50-57. doi: 10.1016/j.aquaculture.2013.03.030

Chabrillón, M., Arijo, S., Díaz-Rosales, P., Balebona, M. C., and Moriñigo, M. A. (2006). Interference of Listonella anguillarum with potential probiotic microorganisms isolated from farmed gilthead seabream (Sparus aurata L.). Aquac. Res. 37, 78-86. doi: 10.1111/j.1365-2109.2005.01400.x

Chabrillon, M., Ouwehand, A. C., Diaz-Rosales, P., Arijo, S., MartinezManzanares, E., Balebona, M. C., et al. (2006). Adhesion of lactic acid bacteria to mucus of farmed gilthead seabream, and interactions with fish pathogenic microorganisms. B. Eur Assoc. Fish. Pat. 26, 202-210.

Chabrillón, M., Rico, R., Arijo, S., Díaz-Rosales, P., Balebona, M., and Moriñigo, M. (2005). Interactions of microorganisms isolated from gilthead sea bream, Sparus aurata L., on Vibrio harveyi, a pathogen of farmed Senegalese sole, Solea senegalensis (Kaup). J. Fish. Dis. 28, 531-537. doi: 10.1111/j.1365-2761.2005.00657.x

Chai, P. C., Song, X. L., Chen, G. F., Xu, H., and Huang, J. (2016). Dietary supplementation of probiotic Bacillus PC465 isolated from the gut of Fenneropenaeus chinensis improves the health status and resistance of Litopenaeus vannamei against white spot syndrome virus. Fish Shellfish Immun. 54, 602-611. doi: 10.1016/j.fsi.2016.05.011

Chang, C. I., and Liu, W. Y. (2002). An evaluation of two probiotic bacterial strains, Enterococcus faecium SF68 and Bacillus toyoi, for reducing edwardsiellosis in cultured European eel (Anguilla anguilla). J. Fish. Dis. 25, 311-315. doi: 10.1046/j.1365-2761.2002.00365.x

Cheng, G., Hao, H., Xie, S., Wang, X., Dai, M., Huang, L. et al. (2014). Antibiotic alternatives: the substitution of antibiotics in animal husbandry? Front. Microbiol. 5:217. doi: 10.3389/fmicb.2014. 00217 
Chi, C., Jiang, B., Yu, X. B., Liu, T. Q., Xia, L., and Wang, G. X. (2014). Effects of three strains of intestinal autochthonous bacteria and their extracellular products on the immune response and disease resistance of common carp, Cyprinus carpio. Fish Shellfish Immun. 36, 9-18. doi: 10.1016/j.fsi.2013.10.003

Chiu, C. H., Cheng, C. H., Gua, W. R., Guu, Y. K., and Cheng, W. (2010). Dietary administration of the probiotic Saccharomyces cerevisiae P13, enhanced the growth, innate immune responses, and diseases resistance of the grouper (Epinephelus coioides). Fish Shellfish Immun. 29, 1053-1059. doi: 10.1016/j.fsi.2010.08.019

Chiu, C. H., Guu, Y. K., Liu, C. H., Pan, T. M., and Cheng, W. (2007). Immune responses and gene expression in white shrimp, Litopenaeus vannamei, induced by Lactobacillus plantarum. Fish Shellfish Immun. 23, 364-377. doi: 10.1016/j.fsi.2006.11.010

D’Alvise, D. W., Lillebø, S., Prol-Garcia, M. J., Wergeland, H. I., Nielsen, K. F., Bergh, Ø., et al. (2012). Phaeobacter gallaeciensis reduces Vibrio anguillarum in cultures of microalgae and rotifers, and prevents vibriosis in cod larvae. PLoS ONE 7:e43996. doi: 10.1371/journal.pone.0043996

Das, S., Ward, L. R., and Burke, C. (2010). Screening of marine Streptomyces spp. for potential use as probiotics in aquaculture. Aquaculture 305, 32-41. doi: 10.1016/j.aquaculture.2010.04.001

Dash, G., Raman, R. P., Prasad, K. P., Makesh, M., Pradeep, M. A., and Sen, S. (2015). Evaluation of paraprobiotic applicability of Lactobacillus plantarum in improving the immune response and disease protection in giant freshwater prawn, Macrobrachium rosenbergii (de Man, 1879). Fish Shellfish Immun. 43, 167-174. doi: 10.1016/j.fsi.2014.12.007

Dawood, M. A. O., and Koshio, S. (2016). Recent advances in the role of probiotics and prebiotics in carp aquaculture: a review. Aquaculture 454, 243-251. doi: 10.1016/j.aquaculture.2015.12.033

De la Banda, I. G., Lobo, C., Chabrillon, M., Leon-Rubio, J. M., Arijo, S., Pazos, G., et al. (2012). Influence of dietary administration of a probiotic strain Shewanella putrefaciens on Senegalese sole (Solea senegalensis, Kaup 1858) growth, body composition and resistance to Photobacterium damselae subsp piscicida. Aquac. Res. 43, 662-669. doi: 10.1111/j.1365-2109.2011.02871.x

Decamp, O., Moriarty, D. J., and Lavens, P. (2008). Probiotics for shrimp larviculture: review of field data from Asia and Latin America. Aquac. Res. 39, 334-338. doi: 10.1111/j.1365-2109.2007.01664.x

Diaz-Rosales, P., Arijo, S., Chabrillon, M., Alarcón, F. J., Tapia-Paniagua, S. T., Martínez-Manzanares, E., et al. (2009). Effects of two closely related probiotics on respiratory burst activity of Senegalese sole (Solea senegalensis, Kaup) phagocytes, and protection against Photobacterium damselae subsp. piscicida. Aquaculture 293, 16-21. doi: 10.1016/j.aquaculture.2009.03.050

Direkbusarakom, S., Yoshimizu, M., Ezura, Y., Ruangpan, L., and Danayadol, Y. (1998). Vibrio spp. the dominant flora in shrimp hatchery against some fish pathogenic viruses. J. Mar. Biotechnol. 6, 266-267.

El-Haroun, E., Goda, A. S., and Chowdhury, K. (2006). Effect of dietary probiotic Biogen ${ }^{\circledR}$ supplementation as a growth promoter on growth performance and feed utilization of Nile tilapia Oreochromis niloticus (L.). Aquac. Res. 37, 1473-1480. doi: 10.1111/j.1365-2109.2006.01584.x

Eshaghzadeh, H., Hoseinifar, S. H., Vahabzadeh, H., and Ringø, E. (2015). The effects ofdietary inulin on growth performances, survival and digestive enzyme activities of common carp (Cyprinus carpio) fry. Aquacult Nutr. 21, 242-247. doi: 10.1111/anu.12155

Faramarzi, M., Kiaalvandi, S., and Iranshahi, F. (2011). The effect of probiotics on growth performance and body composition of common carp (Cyprinus carpio). J. Anim. Vet. Adv. 10, 2408-2413. doi: 10.3923/javaa.2011.2408.2413

Ferreira, G. S., Bolívar, N. C., Pereira, S. A., Guertler, C., do Nascimento Vieira, F., Mouriño, J. L. P., et al. (2015). Microbial biofloc as source of probiotic bacteria for the culture of Litopenaeus vannamei. Aquaculture 448, 273-279. doi: 10.1016/j.aquaculture.2015.06.006

Gildberg, A., Mikkelsen, H., Sandaker, E., and Ringø, E. (1997). Probiotic effect of lactic acid bacteria in the feed on growth and survival of fry of Atlantic cod (Gadus morhua). Hydrobiologia 352, 279-285. doi: 10.1023/A:1003052111938

Giri, S. S., Sen, S. S., and Sukumaran, V. (2012). Effects of dietary supplementation of potential probiotic Pseudomonas aeruginosa VSG-2 on the innate immunity and disease resistance of tropical freshwater fish, Labeo rohita. Fish Shellfish Immun. 32, 1135-1140. doi: 10.1016/j.fsi.2012.03.019

Gobeli, S., Goldschmidt-Clermont, E., Frey, J., and Burr, S. E. (2009). Pseudomonas chlororaphis strain JF3835 reduces mortality of juvenile perch,
Perca fluviatilis L., caused by Aeromonas sobria. J. Fish. Dis. 32, 597-602. doi: 10.1111/j.1365-2761.2009.01021.x

Gram, L., Lovold, T., Nielsen, J., Melchiorsen, J., and Spanggaard, B. (2001). In vitro antagonism of the probiont Pseudomonas fluorescens strain $\mathrm{AH} 2$ against Aeromonas salmonicida does not confer protection of salmon against furunculosis. Aquaculture 199, 1-11. doi: 10.1016/S0044-8486(01) 00565-8

Gram, L., Melchiorsen, J., Spanggaard, B., Huber, I., and Nielsen, T. F. (1999). Inhibition of Vibrio anguillarum by Pseudomonas fluorescens AH2, a possible probiotic treatment of fish. Appl. Environ. Microb. 65, 969-973.

Hai, N. V. (2015). Research findings from the use of probiotics in tilapia aquaculture: a review. Fish Shellfish Immun. 45, 592-597. doi: 10.1016/j.fsi.2015.05.026

Hai, N. V., Buller, N., and Fotedar, R. (2010). Effect of customized probiotics on the physiological and immunological responses of juvenile western king prawns (Penaeus latisulcatus Kishinouye, 1896) challenged with Vibrio harveyi. J. Appl. Aquac. 22, 321-336. doi: 10.1080/10454438.2010.527580

Han, B., Long, W. Q., He, J. Y., Liu, Y. J., Si, Y. Q., and Tian, L. X. (2015) Effects of dietary Bacillus licheniformis on growth performance, immunological parameters, intestinal morphology and resistance of juvenile Nile tilapia (Oreochromis niloticus) to challenge infections. Fish Shellfish Immun. 46, 225-231. doi: 10.1016/j.fsi.2015.06.018

Harikrishnan, R., Balasundaram, C., and Heo, M. S. (2010). Effect of probiotics enriched diet on paralichthys olivaceus infected with lymphocystis disease virus (LCDV). Fish Shellfish Immun. 29, 868-874. doi: 10.1016/j.fsi.2010.07.031

Harikrishnan, R., Kim, M. C., Kim, J. S., Balasundaran, C., and Heo, M. S. (2011). Protective effect of herbal and probiotics enriched diet on haematological and immunity status of Oplegnathus fasciatus (Temminck and Schlegel) against Edwarsiella tarda. Fish. Shellfish Immun. 30, 886-893. doi: 10.1016/j.fsi.2011.01.013

Heo, W. S., Kim, Y. R., Kim, E. Y., Bai, S. C., and Kong, I. S. (2013). Effects of dietary probiotic, Lactococcus lactis subsp. lactis I2, supplementation on the growth and immune response of olive flounder (Paralichthys olivaceus). Aquaculture 376, 20-24. doi: 10.1016/j.aquaculture.2012.11.009

Hjelm, M., Bergh, O., Riaza, A., Nielsen, J., Melchiorsen, J., Jensen, S., et al. (2004). Selection and identification of autochthonous potential probiotic bacteria from turbot larvae (Scophthalmus maximus) rearing units. Syst. Appl. Microbiol. 27, 360-371. doi: 10.1078/0723-2020-00256

Hoseinifar, S. H., Dadar, M., and Ringø, E. (2017a). Modulation of nutrient digestibility and digestive enzyme activities in aquatic animals: the functional feed additives scenario. Aquac. Res. 48, 3987-4000. doi: 10.1111/are.13368

Hoseinifar, S. H., Eshaghzadeh, H., Vahabzadeh, H., and Peykaran Mana, N. (2015a). Modulation of growth performances, survival, digestive enzyme activities and intestinal microbiota in common carp (Cyprinus carpio) larvae using short chain fructooligosaccharide. Aquac. Res. 47, 3246-3253. doi: 10.1111/are.12777

Hoseinifar, S. H., Mirvaghefi, A., Amoozegar, M. A., Sharifian, M., and Esteban, M. Á. (2015b). Modulation of innate immune response, mucosal parameters and disease resistance in rainbow trout (Oncorhynchus mykiss) upon synbiotic feeding. Fish Shellfish Immun. 45, 27-32. doi: 10.1016/j.fsi.2015. 03.029

Hoseinifar, S. H., Ringø, E., Shenavar Masouleh, A., and Esteban, M. Á. (2016). Probiotic, prebiotic and synbiotic supplements in sturgeon aquaculture: a review. Rev. Aquacult. 8, 89-102. doi: 10.1111/raq.12082

Hoseinifar, S. H., Sun, Y., and Caipang, C. M. (2017b). Short chain fatty acids as feed supplements for sustainable aquaculture: an updated view. Aquac. Res. 48, 1380-1391. doi: 10.1111/are.13239

Hotel, A., and Córdoba, A. (2001). Health and nutritional properties of probiotics in food including powder milk with live lactic acid bacteria. Prevention 5, 1-10

Huang, J., Wu, Y., and Chi, S. (2014). Dietary supplementation of Pediococcus pentosaceus enhances innate immunity, physiological health and resistance to Vibrio anguillarum in orange-spotted grouper (Epinephelus coioides). Fish Shellfish Immun. 39, 196-205. doi: 10.1016/j.fsi.2014. 05.003

Irianto, A., and Austin, B. (2002). Probiotics in aquaculture. Fish Shellfish Immun. 25, 633-642.

Irianto, A., Robertson, P. A. W., and Austin, B. (2003). Oral administration of formalin-inactivated cells of Aeromonas hydrophila A3-51 controls infection by 
a typical A. salmonicida in goldfish, (Carassius auratus). Fish Shellfish Immun. 26, 117-120. doi: 10.1046/j.1365-2761.2003.00439.x

Jöborn, A., Olsson, J. C., Westerdahl, A., Conway, P. L., and Kjelleberg, S. (1997). Colonization in the fish intestinal tract and production of inhibitory substances in intestinal mucus and faecal extracts by Carnobacterium sp. strain K1. Fish Shellfish Immun. 20, 383-392.

Kesarcodi-Watson, A., Kaspar, H., Lategan, M. J., and Gibson, L. (2010). Alteromonas macleodii 0444 and Neptunomonas sp. 0536, two novel probiotics for hatchery-reared Greenshell (TM) mussel larvae, Perna canaliculus. Aquaculture 309, 49-55. doi: 10.1016/j.aquaculture.2010.09.019

Kesarcodi-Watson, A., Miner, P., Nicolas, J. L., and Robert, R. (2012). Protective effect of four potential probiotics against pathogen-challenge of the larvae of three bivalves: pacific oyster (Crassostrea gigas), flat oyster (Ostrea edulis) and scallop (Pecten maximus). Aquaculture 344, 29-34. doi: 10.1016/j.aquaculture.2012.02.029

Kim, D., Beck, B. R., Heo, S. -B., Kim, J., Kim, H. B., Lee, S. -M., et al. (2013). Lactococcus lactis BFE920 activates the innate immune system of olive flounder (Paralichthys olivaceus), resulting in protection against Streptococcus iniae infection and enhancing feed efficiency and weight gain in large scale field-studies. Fish Shellfish Immun. 35, 1585-1590. doi: 10.1016/j.fsi.2013. 09.008

Kim, D. -H., and Austin, B. (2006a). Innate immune responses in rainbow trout (Oncorhynchus mykiss, Walbaum) induced by probiotics. Fish Shellfish Immun. 21, 513-524. doi: 10.1016/j.fsi.2006.02.007

Kim, D. -H., and Austin, B. (2006b). Cytokine expression in leucocytes and gut cells of rainbow trout, Oncorhynchus mykiss Walbaum, induced by probiotics. Vet. Immunol. Immun. 114, 297-304. doi: 10.1016/j.vetimm.2006.08.015

Kim, J. S., Harikrishnan, R., Kim, M. C., Balasundaram, C., and Heo, M. S. (2010). Dietary administration of Zooshikellasp. to enhance the innate immune response and disease resistance of Paralichthys olivaceus against Streptococcus iniae. Fish Shellfish Immun. 29, 104-110. doi: 10.1016/j.fsi.2010.02.022

Korkea-aho, T. L., Heikkinen, J., Thompson, K. D., von Wright, A., and Austin, B. (2011). Pseudomonas sp. M174 inhibits the fish pathogen Flavobacterium psychrophilum. J. Appl. Microbiol. 111, 266-277. doi: 10.1111/j.1365-2672.2011.05044.x

Korkea-aho, T. L., Papadopoulou, A., Heikkinen, J., von Wright, A., Adams, A., Austin, B., et al. (2012). Pseudomonas M162 confers protection against rainbow trout fry syndrome by stimulating immunity. J. Appl. Microbiol. 113, 24-35. doi: $10.1111 / j .1365-2672.2012 .05325 . x$

Kumar, R., Mukherjee, S., Ranjan, R., and Nayak, S. (2008). Enhanced innate immune parameters in Labeo rohita (Ham.) following oral administration of Bacillus subtilis. Fish Shellfish Immun. 24, 168-172. doi: 10.1016/j.fsi.2007.10.008

Kumar, R., Mukherjee, S. C., Pani Prasad, K., and Pal, A. K. (2006) Evaluation of Bacillus subtilis as a probiotic to Indian major carp, Labeo rohita (Ham). Aquac. Res. 37, 1215-1221. doi: 10.1111/j.1365-2109.2006.01551.x

Lakshmi, B., Viswanath, B., and SaiGopal, D. V. R. (2013). Probiotics as antiviral agents in shrimp aquaculture. J. Pathogens 2013:424123. doi: $10.1155 / 2013 / 424123$

Lazado, C. C., Caipang, C. M. A., Brinchmann, M. F., and Kiron, V. (2011). In vitro adherence of two candidate probiotics from Atlantic cod and their interference with the adhesion of two pathogenic bacteria. Vet. Microbiol. 148, 252-259. doi: 10.1016/j.vetmic.2010. 08.024

Lee, J. S., Cheng, H., Damte, D., Lee, S. J., Kim, J. C., Rhee, M. H., et al. (2013). Effects of dietary supplementation of Lactobacillus pentosus PL11 on the growth performance, immune and antioxidant systems of Japanese eel Anguilla japonica challenged with Edwardsiella tarda. Fish Shellfish Immun. 34, 756-761. doi: $10.1016 /$ j.fsi.2012.11.028

Leonel Ochoa-Solano, J., and Olmos-Soto, J. (2006). The functional property of Bacillus for shrimp feeds. Food Microbiol. 23, 519-525. doi: 10.1016/j.fm.2005. 10.004

Leyton, Y. E., Varas Psijas, R. A., and Riquelme, C. E. (2012). Probiotic activity of bacteria associated with egg capsules of Concholepas concholepas (common name 'Loco'). Aquacult. Res. 43, 1089-1095. doi: 10.1111/j.1365-2109.2011.02912.x

Leyva-Madrigal, K. Y., Luna-González, A., Escobedo-Bonilla, C. M., FierroCoronado, J. A., and Maldonado-Mendoza, I. E. (2011). Screening for potential probiotic bacteria to reduce prevalence of WSSV and IHHNV in whiteleg shrimp (Litopenaeus vannamei) under experimental conditions. Aquaculture 322, 16-22. doi: 10.1016/j.aquaculture.2011.09.033

Li, J., Tan, B., and Mai, K. (2009). Dietary probiotic Bacillus OJ and isomaltooligosaccharides influence the intestine microbial populations, immune responses and resistance to white spot syndrome virus in shrimp (Litopenaeus vannamei). Aquaculture 291, 35-40. doi: 10.1016/j.aquaculture.2009.03.005

Li, J., Tan, B., Mai, K., Ai, Q., Zhang, W., Liufu, Z., et al. (2006). Comparative study between probiotic bacterium Arthrobacter XE-7 and chloramphenicol on protection of Penaeus chinensis post-larvae from pathogenic vibrios. Aquaculture 253, 140-147. doi: 10.1016/j.aquaculture.2005.07.040

Li, J., Tan, B., Mai, K., Ai, Q., Zhang, W., Liufu, Z., et al. (2008). Immune responses and resistance against Vibrio parahaemolyticus induced by probiotic bacterium Arthrobacter XE-7 in Pacific White Shrimp, Litopenaeus vannamei. J. World. Aquacult. Soc. 39, 477-489. doi: 10.1111/j.1749-7345.2008.0 0188.x

Liu, C. H., Chiu, C. H., Wang, S. W., and Cheng, W. (2012). Dietary administration of the probiotic, Bacillus subtilis E20, enhances the growth, innate immune responses, and disease resistance of the grouper, Epinephelus coioides. Fish Shellfish Immun. 33, 699-706. doi: 10.1016/j.fsi.2012.06.012

Liu, H., Li, Z., Tan, B., Lao, Y., Duan, Z., Sun, W., et al. (2014). Isolation of a putative probiotic strain S12 and its effect on growth performance, non-specific immunity and disease-resistance of white shrimp, Litopenaeus vannamei. Fish Shellfish Immun. 41, 300-307. doi: 10.1016/j.fsi.2014.08.028

Liu, W., Ren, P., He, S., Xu, L., Yang, Y., Gu, Z., et al. (2013). Comparison of adhesive gut bacteria composition, immunity, and disease resistance in juvenile hybrid tilapia fed two different Lactobacillus strains. Fish Shellfish Immun. 35, 54-62. doi: 10.1016/j.fsi.2013.04.010

Llewellyn, M. S., Boutin, S., Hoseinifar, S. H., and Derome, N. (2014). Teleost microbiomes: the state of the art in their characterization, manipulation and importance in aquaculture and fisheries. Front. Microbiol. 5:207. doi: $10.3389 /$ fmicb.2014.00207

Løvmo Martinsen, L., Salma, W., Myklebust, R., Mayhew, T. M., and Ringø, E. (2011). Carnobacterium maltaromaticum vs. Vibrio (Listonella) anguillarum in the midgut of Atlantic cod (Gadus morhua L.): an ex vivo study. Aquac. Res. 42, 1830-1839. doi: 10.1111/j.1365-2109.2010.02784.x

Luis-Villaseñor, I. E., Macías-Rodríguez, M. E., Gómez-Gil, B., Ascencio-Valle, F., and Campa-Córdova, Á. I. (2011). Beneficial effects of four Bacillus strains on the larval cultivation of Litopenaeus vannamei. Aquaculture 321, 136-144. doi: 10.1016/j.aquaculture.2011.08.036

Ma, C. -W., Cho, Y. -S., and Oh, K. -H. (2009). Removal of pathogenic bacteria and nitrogens by Lactobacillus spp. JK-8 and JK-11. Aquaculture 287, 266-270. doi: 10.1016/j.aquaculture.2008.10.061

Macey, B. M., and Coyne, V. E. (2006). Colonization of the gastrointestinal tract of the farmed South African abalone Haliotis midae by the probionts Vibrio midae SY9, Cryptococcus sp. SS1, and Debaryomyces hansenii AY1. Mar. Biotechnol. 8, 246-259. doi: 10.1007/s10126-005-0113-9

Maeda, M., Nogami, K., Kanematsu, M., and Hirayama, K. (1997). The concept of biological control methods in aquaculture. Hydrobiologia 358, 285-290.

Mahdhi, A., Kamoun, F., Messina, C., Santulli, A., and Bakhrouf, A. (2012). Probiotic properties of Brevibacillus brevis and its influence on sea bass (Dicentrarchus labrax) larval rearing. Afr. J. Microbiol. Res. 6, 6487-6495. doi: 10.5897/AJMR12.1201

Merrifield, D. L., Balcazar, J. L., Daniels, C. L., Zhou, Z., Carnevali, O., Sun, Y. Z., et al. (2014). "Indigenous lactic acid bacteria in fish and crustaceans," in Aquaculture Nutrition: Gut Health, Probiotics and Prebiotics [M], eds D. L. Merrifield and E. Ringø (West Sussex: Wiley-Blackwell), 128-168.

Merrifield, D. L., Bradley, G., Baker, R., and Davies, S. (2010a). Probiotic applications for rainbow trout (Oncorhynchus mykiss Walbaum) II. Effects on growth performance, feed utilization, intestinal microbiota and related health criteria postantibiotic treatment. Aquacult. Nutr. 16, 496-503. doi: 10.1111/j.1365-2095.2009.00688.x

Merrifield, D. L., and Carnevali, O. (2014). Probiotic Modulation of the Gut Microbiota of Fish. Aquaculture Nutrition: Gut Health, Probiotics and Prebiotics. Hoboken, NJ: John Wiley and Sons, Ltd.

Merrifield, D. L., Dimitroglou, A., Foey, A., Davies, S. J., Baker, R. T., Bøgwald, J., et al. (2010b). The current status and future focus of 
probiotic and prebiotic applications for salmonids. Aquaculture 302, 1-18. doi: 10.1016/j.aquaculture.2010.02.007

Mingmongkolchai, S., and Panbangred, W. (2018). Bacillus probiotics: an alternative to antibiotics for livestock production. J. Appl. Microbiol. 124, 1334-1346. doi: 10.1111/jam.13690

Modanloo, M., Soltanian, S., Akhlaghi, M., and Hoseinifar, S. H. (2017). The effects of single or combined administration of galactooligosaccharide and Pediococcus acidilactici on cutaneous mucus immune parameters, humoral immune responses and immune related genes expression in common carp (Cyprinus carpio) fingerlings. Fish Shellish Immun. 70, 391-397. doi: $10.1016 /$ j.fsi.2017.09.032

Montes, A., and Pugh, D. (1993). The use of probiotics in food-animal practice. Vet. Med. 88, 282-288.

Moriarty, D. (1998). Control of luminous Vibrio species in penaeid aquaculture ponds. Aquaculture 164, 351-358. doi: 10.1016/S0044-8486(98)00199-9

Mujeeb Rahiman, K. M., Jesmi, Y., Thomas, A. P., and Mohamed Hatha, A. A. (2010). Probiotic effect of Bacillus NL110 and Vibrio NE17 on the survival, growth performance and immune response of Macrobrachium rosenbergii (de Man). Aquac. Res. 41, e120-e134. doi: 10.1111/j.1365-2109.2009. 02473.x

Nayak, S., Swain, P., and Mukherjee, S. (2007). Effect of dietary supplementation of probiotic and vitamin $\mathrm{C}$ on the immune response of Indian major carp, Labeo rohita (Ham.). Fish Shellfish Immun. 23, 892-896. doi: 10.1016/j.fsi.2007.02.008

Newaj-Fyzul, A., Adesiyun, A. A., Mutani, A., Ramsubhag, A., Brunt, J., and Austin, B. (2007). Bacillus subtilis AB1 controls Aeromonas infection in rainbow trout (Oncorhynchus mykiss, Walbaum). J. Appl. Microb. 103, 1699-1706. doi: $10.1111 / j .1365-2672.2007 .03402 . x$

Ng, W. K., Kim, Y. C., Romano, N., Koh, C. B., and Yang, S. Y. (2014). Effects of dietary probiotics on the growth and feeding efficiency of red hybrid Tilapia, Oreochromis sp., and subsequent resistance to Streptococcus agalactiae. J. Appl. Aquac. 26, 22-31. doi: 10.1080/10454438.2013.874961

Nikoskelainen, S., Ouwehand, A. C., Bylund, G., Salminen, S., and Lilius, E. -M. (2003) Immune enhancement in rainbow trout (Oncorhynchus mykiss) by potential probiotic bacteria (Lactobacillus rhamnosus). Fish Shellfish Immun. 15, 443-452. doi: 10.1016/S1050-4648(03)00023-8

Nikoskelainen, S., Salminen, S., Bylund, G., and Ouwehand, A. C. (2001). Characterization of the properties of human and dairy derived probiotics for prevention of infectious diseases in fish. Appl. Environ. Micro. 67, 2430-2435. doi: 10.1128/AEM.67.6.2430-2435.2001

Pai, S. S., Anas, A., Jayaprakash, N. S., Priyaja, P., Sreelakshmi, B., Preetha, R., et al. (2010). Penaeus monodon larvae can be protected from Vibrio harveyi infection by pre-emptive treatment of a rearing system with antagonistic or non-antagonistic bacterial probiotics. Aquac. Res. 41, 847-860. doi: 10.1111/j.1365-2109.2009.02362.x

Pan, X., Wu, T., Song, Z., Tang, H., and Zhao, Z. (2008b). Immune responses and enhanced disease resistance in Chinese drum, Miichthys miiuy (Basilewsky), after oral administration of live or dead cells of Clostridium butyricum CB2. J. Fish. Dis. 31, 679-686. doi: 10.1111/j.1365-2761.2008.00955.x

Pan, X., Wu, T., Zhang, L., Song, Z., Tang, H., and Zhao, Z. (2008a). In vitro evaluation on adherence and antimicrobial properties of a candidate probiotic Clostridium butyricum CB2 for farmed fish. J. Appl. Microbiol. 105, 1623-1629. doi: $10.1111 / j .1365-2672.2008 .03885 . x$

Parker, R. (1974). Probiotics, the other half of the antibiotic story. Animal Nutr. Health 29, 4-8.

Partida-Arangure, B. O., Luna-González, A., Fierro-Coronado, J. A., FloresMiranda, C., and González-Ocampo, H. A. (2013). Effect of inulin and probiotic bacteria on growth, survival, immune response, and prevalence of white spot syndrome virus (WSSV) in Litopenaeus vannamei cultured under laboratory conditions. Afr. J. Bio. 12, 3366-3375. doi: 10.5897/AJB12.1569

Pérez-Sánchez, T., Balcázar, J. L., Merrifield, D. L., Carnevali, O., Gioacchini, G., de Blas, I., et al. (2011). Expression of immune-related genes in rainbow trout (Oncorhynchus mykiss) induced by probiotic bacteria during Lactococcus garvieae infection. Fish Shellfish Immun. 31, 196-201. doi: 10.1016/j.fsi.2011.05.005

Pieters, N., Brunt, J., Austin, B., and Lyndon, A. R. (2008). Efficacy of in-feed probiotics against Aeromonas bestiarum and Ichthyophthirius multifilisskin infections in rainbow trout (Oncorhynchus mykiss, Walbaum). J. Appl. Microb. 105, 723-732. doi: 10.1111/j.1365-2672.2008.03817.x
Pirarat, N., Kobayashi, T., Katagiri, T., Maita, M., and Endo, M. (2006). Protective effects and mechanisms of a probiotic bacterium Lactobacillus rhamnosus against experimental Edwardsiella tarda infection in tilapia (Oreochromis niloticus). Vet. Immunol. Immunop. 113, 339-347. doi: 10.1016/j.vetimm.2006.06.003

Pirarat, N., Pinpimai, K., Endo, M., Katagiri, T., Ponpornpisit, A., Chansue, N., et al. (2011). Modulation of intestinal morphology and immunity in nile tilapia (Oreochromis niloticus) by Lactobacillus rhamnosus GG. Res. Vet. Sci. 91, e92-e97. doi: 10.1016/j.rvsc.2011.02.014

Planas, M., Pérez-Lorenzo, M., Hjelm, M., Gram, L., Fiksdal, I. U., Bergh, Ø., et al. (2006). Probiotic effect in vivo of Roseobacter strain 27-4 against Vibrio (Listonella) anguillarum infections in turbot (Scophthalmus maximus L.) larvae. Aquaculture 255, 323-333. doi: 10.1016/j.aquaculture.2005.11.039

Quentel, C., Gatesoupe, F. J., Aubin, J., Lamour, F., Abiven, A., Baud, M., et al. (2005). "Ofimer probiotic study on rainbow trout. I. Resistance against Yersinia ruckeri and humoral immune response of rainbow trout (Oncorhynchus mykiss) submitted to probiotic treatment with Saccharomyces cerevisiae var. boulardii," in Lessons from the Past to Optimise the Future. Aquaculture Europe 2005, Trondheim, EAS Special Publication, Vol 35. eds B. Howell and R. Flos (Oostende: European Aquaculture Society), 380-381.

Raa, J. (1996). The use of immunostimulatory substances in fish and shellfish farming. Rev. Fish. Sci. 4, 229-288. doi: 10.1080/10641269609388587

Rafiee, G., and Saad, C. R. (2005). Nutrient cycle and sludge production during different stages of red tilapia (Oreochromis sp.) growth in a recirculating aquaculture system. Aquaculture 244, 109-118. doi: 10.1016/j.aquaculture.2004.10.029

Raida, M. K., Larsen, J. L., Nielsen, M. E., and Buchmann, K. (2003). Enhanced resistance of rainbow trout (Oncorhynchus myskiss) against Yersinia ruckeri challenge following oral administration of Bacillus subtilis and B. licheniformis (Bio plus 2B). J. Fish. Dis. 26, 495-498. doi: 10.1046/j.1365-2761.2003. 00480.x

Ramesh, D., Vinothkanna, A., Rai, A. K., and Vignesh, V. S. (2015). Isolation of potential probiotic Bacillus spp. and assessment of their subcellular components to induce immune responses in Labeo rohita against Aeromonas hydrophila. Fish Shellfish Immun. 45, 268-276. doi: 10.1016/j.fsi.2015. 04.018

Ran, C., Carrias, A., Williams, M. A., Capps, N., and Dan, B. C. T. (2012). Identification of Bacillus strains for biological control of catfish pathogens. PLoS ONE 7:e45793. doi: 10.1371/journal.pone.0045793

Ravi, A., Musthafa, K., Jegathammbal, G., Kathiresan, K., and Pandian, S. (2007). Screening and evaluation of probiotics as a biocontrol agent against pathogenic Vibrios in marine aquaculture. Lett. Appl. Microbiol. 45, 219-223. doi: 10.1111/j.1472-765X.2007.02180.x

Remus, D. M., van Kranenburg, R., van Swam, I. I., Taverne, N., Bongers, R. S., Wels, M., et al. (2012). Impact of 4 Lactobacillus plantarum capsular polysaccharide clusters on surface glycan composition and host cell signaling. Microb. Cell. Fact. 11:149. doi: 10.1186/1475-2859-11-149

Rengpipat, S., Phianphak, W., Piyatiratitivorakul, S., and Menasveta, P. (1998). Effects of a probiotic bacterium on black tiger shrimp Penaeus monodon survival and growth. Aquaculture 167, 301-313. doi: 10.1016/S0044-8486(98)00305-6

Rengpipat, S., Rukpratanporn, S., Piyatiratitivorakul, S., and Menasaveta, P. (2000). Immunity enhancement in black tiger shrimp (Penaeus monodon) by a probiont bacterium (Bacillus S11). Aquaculture 191, 271-288. doi: 10.1016/S0044-8486(00)00440-3

Rengpipat, S., Tunyanun, A., Fast, A. W., Piyatiratitivorakul, S., and Menasveta, P. (2003). Enhanced growth and resistance to Vibrio challenge in pond-reared black tiger shrimp Penaeus monodon fed a Bacillus probiotic. Dis. Aquat. Organ. 55, 169-173. doi: 10.3354/dao055169

Reyes-Becerril, M., Tovar-Ramírez, D., Ascensio-Valle, F., Civera-Cerecedo, R., Gracia-López, V., Barbosa-Solomieu, V., et al. (2011). Effects of dietary supplementation with probiotic live yeast Debaryomyces hansenii on the immune and antioxidant systems of leopard grouper Mycteroperca rosacea infected with Aeromonas hydrophila. Aquac. Res. 42, 1676-1686. doi: 10.1111/j.1365-2109.2010.02762.x

Ringø, E. (2008). The ability of carnobacteria isolated from fish intestine to inhibit growth of fish pathogenic bacteria: a screening study. Aquac. Res. 39, 171-180. doi: 10.1111/j.1365-2109.2007.01876.x 
Ringø, E., Løvmo, L., Kristiansen, M., Bakken, Y., Salinas, I., Myklebust, R., et al. (2010). Lactic acid bacteria $v s$. pathogens in the gastrointestinal tract of fish: a review. Aquac. Res. 41, 451-467. doi: 10.1111/j.1365-2109.2009. 02339.x

Ringø, E., Sepploa, M., Berg, A., Olsen, R. E., Schillinger, U., Holzapfel, W. (2002). Characterization of Carnobacterium divergens strain 6251 isolated from intestine of Arctic charr (Salvelinus alpinus L.). Syst. Appl. Microbiol. 25, 120-129. doi: 10.1078/0723-2020-00080

Ringø, E., Zhou, Z., Vecino, J. L. G., Wadsworth, S., Romero, J., Krogdahl, Å., et al. (2016). Effect of dietary components on the gut microbiota of aquatic animals. A never-ending story? Aquacult. Nutr. 22, 219-282. doi: 10.1111/anu. 12346

Robertson, P. A. W., O’Dowd, C., Burrells, C., Williams, P., and Austin, B. (2000). Use of Carnobacterium sp. as a probiotic for Atlantic salmon (Salmo salar L.) and rainbow trout (Oncorhynchus mykiss, Walbaum). Aquaculture 185, 235-243. doi: 10.1016/S0044-8486(99)00349-X

Rodríguez, J., Espinosa, Y., Echeverria, F., Cárdenas, G., Román, R., and Stern, S. (2007). Exposure to probiotics and $\beta-1,3 / 1,6$-glucans in larviculture modifies the immune response of Penaeus vannamei juveniles and both the survival to White Spot Syndrome Virus challenge and pond culture. Aquaculture 273, 405-415. doi: 10.1016/j.aquaculture.2007. 10.042

Rodríguez-Estrada, U., Satoh, S., Haga, Y., Fushimi, H., and Sweetman, J. (2013). Effects of inactivated Enterococcus faecalis and mannan oligosaccharide and their combination on growth, immunity, and disease protection in rainbow trout. North Am. J. Aquacult. 75, 416-428. doi: 10.1080/15222055.2013. 799620

Rohyati, I. S. (2015). Improved of growth rate of abalone haliotis asinine fed pudding probiotic-enriched protein. Procedia Environ. Sci. 23, 315-322. doi: 10.1016/j.proenv.2015.01.046

Safari, R., Adel, M., Lazado, C. C., Caipang, C. M., and Dadar, M. (2016). Host-derived probiotics Enterococcus casseliflavus improves resistance against Streptococcus iniae infection in rainbow trout (Oncorhynchus mykiss) via immunomodulation. Fish Shellfish Immun. 52, 198-205. doi: 10.1016/j.fsi.2016.03.020

Sakai, M., Yoshida, T., Atsuta, S., and Kobayashi, M. (1995). Enhancement of resistance to vibriosis in rainbow trout, Oncorhynchus mykiss (Walbaum), by oral administration of Clostridium butyricum bacterin. J. Fish. Dis. 18, 187-190. doi: 10.1111/j.1365-2761.1995.tb0 0276.x

Salinas, I., Myklebust, R., Esteban, M. A., Olsen, R. E., Meseguer, J., and Ringø E. (2008). In vitro studies of Lactobacillus delbrueckii subsp. lactis in Atlantic salmon (Salmo salar L.) foregut: tissue responses and evidence of protection against Aeromonas salmonicida subsp. salmonicida epithelial damage. Vet. Microbiol. 128, 167-177. doi: 10.1016/j.vetmic.2007. 10.011

Sayes, C., Leyton, Y., and Riquelme, C. (2018). "Probiotic bacteria as an healthy alternative for fish aquaculture," in Antibiotic Use in Animals, ed S. Savic (London: Intech Open) 115-132.

Scholz, U., Garcia Diaz, G., Ricque, D., Cruz Suarez, L. E., Vargas Albores, F., and Latchford, J. (1999). Enhancement of vibriosis resistance in juvenile Penaeus vannamei by supplementation of diets with different yeast products. Aquaculture 176, 271-283.

Selim, K. M., and Reda, R. M. (2015). Improvement of immunity and disease resistance in the Nile tilapia, Oreochromis niloticus, by dietary supplementation with Bacillus amyloliquefaciens. Fish Shellfish Immun. 44, 496-503. doi: 10.1016/j.fsi.2015.03.004

Sha, Y., Wang, L., Liu, M., Jiang, K., Xin, F., and Wang, B. (2016). Effects of lactic acid bacteria and the corresponding supernatant on the survival, growth performance, immune response and disease resistance of Litopenaeus vannamei. Aquaculture 452, 28-36. doi: 10.1016/j.aquaculture.2015.10.014

Sharifuzzaman, S. M., Abbass, A., Tinsley, J. W., and Austin, B. (2011). Subcellular components of probiotics Kocuria SM1 and Rhodococcus SM2 induce protective immunity in rainbow trout (Oncorhynchus mykiss, Walbaum) against Vibrio anguillarum. Fish Shellfish Immun. 30, 347-353. doi: 10.1016/j.fsi.2010.11.005

Sharifuzzaman, S. M., and Austin, B. (2010). Development of protection in rainbow trout (Oncorhynchus mykiss, Walbaum) to Vibrio anguillarum following use of the probiotic Kocuria SM1. Fish Shellfish Immun. 29, 212-216. doi: 10.1016/j.fsi.2010.03.008

Silva-Aciares, F. R., Carvajal, P. O., Mejias, C. A., and Riquelme, C. E. (2011). Use of macroalgae supplemented with probiotics in the Haliotis rufescens (Swainson, 1822) culture in Northern Chile. Aquac. Res. 42, 953-961. doi: 10.1111/j.1365-2109.2010.02678.x

Sivakumar, N., Sundararaman, M., and Selvakumar, G. (2012). Probiotic effect of Lactobacillus acidophilus against Vibriosis in juvenile shrimp (Penaeus monodon). Afr. J. Biotechnol. 11, 15811-15818. doi: 10.5897/AJB12.1328

Soleimani, N., Hoseinifar, S. H., Merrifield, D. L., Barati, M., and Abadi, Z. H. (2012). Dietary supplementation of fructooligosaccharide (FOS) improves the innate immune response, stress resistance, digestive enzyme activities and growth performance of Caspian roach (Rutilus rutilus) fry. Fish Shellfish Immun. 32, 316-321. doi: 10.1016/j.fsi.2011.11.023

Son, V. M., Chang, C. C., Wu, M. C., Guu, Y. K., Chiu, C. H., and Cheng, W. (2009). Dietary administration of the probiotic, Lactobacillusplantarum, enhanced the growth, innate immune responses, and disease resistance of the grouper Epinephelus coioides. Fish Shellfish Immun. 26, 691-698. doi: 10.1016/j.fsi.2009.02.018

Sorroza, L., Padilla, D., Acosta, F., Román, L., Grasso, V., Vega, J., et al. (2012). Characterization of the probiotic strain Vagococcus fluvialis in the protection of European sea bass (Dicentrarchus labrax) against vibriosis by Vibrio anguillarum. Vet. Microbiol. 155, 369-373. doi: 10.1016/j.vetmic.2011.09.013

Sorroza, L., Real, F., Acosta, F., Acosta, B., Deniz,. S., Roman, L., et al. (2013). A probiotic potential of Enterococcus gallinarum against Vibrio anguillarum infection. Fish Pathol. 48, 9-12. doi: 10.3147/jsfp.48.9

Stanier, R. Y., Doudoroff, M., and Adelberg, E. A. (1975). General Microbiology, $3 r d$ Edn. New York, NY: The MacMillan Press.

Sugimura, Y., Hagi, T., and Hoshino, T. (2011). Correlation between in vitro mucus adhesion and the in vivo colonization ability of lactic acid bacteria: screening of new candidate carp probiotics. Biosci. Biotech. Bioch. 75, 511-515. doi: $10.1271 /$ bbb. 100732

Sugita, H., Miyajima, C., and Deguchi, Y. (1991) The vitamin B 12-producing ability of the intestinal microflora of freshwater fish. Aquaculture 92, 267-276. doi: 10.1016/0044-8486(91)90028-6

Sugita, H., Takahashi, J., and Deguchi, Y. (1992). Production and consumption of biotin by the intestinal microflora of cultured freshwater fishes. Biosci. Biotechnol. Biochem. 56, 1678-1679. doi: 10.1271/bbb.56.1678

Sun, Y. Z., Xia, H. Q., Yang, H. L., Wang, Y. L., and Zou, W. C. (2014). TLR2 signaling may play a key role in the probiotic modulation of intestinal microbiota in grouper Epinephelus coioides. Aquaculture 430, 50-56. doi: 10.1016/j.aquaculture.2014.03.042

Sun, Y. Z., Yang, H. L., Huang, K. P., Ye, J. D., and Zhang, C. X. (2013). Application of autochthonous Bacillus bioencapsulated in copepod to grouper Epinephelus coioides larvae. Aquaculture 392-395, 44-50. doi: 10.1016/j.aquaculture.2013.01.037

Sun, Y. Z., Yang, H. L., Ling, Z. C., Chang, J. B., and Ye, J. D. (2009). Gut microbiota of fast and slow growing grouper Epinephelus coioides. Afr. J. Microbiol. Res. 3, 713-720.

Swain, S. M., Singh, C., and Arul, V. (2009). Inhibitory activity of probiotics Streptococcus phocae PI80 and Enterococcus faecium MC13 against vibriosis in shrimp Penaeus monodon. World J. Microbiol. Biotechnol. 25, 697-703. doi: 10.1007/s11274-008-9939-4

Tan, L. T., Chan, K. -G., Lee, L. -H., and Goh, B. -H. (2016). Streptomyces bacteria as potential probiotics in aquaculture. Front. Microbiol. 7:79. doi: $10.3389 /$ fmicb. 2016.00079

Tapia-Paniagua, S. T., Vidal, S., Lobo, C., Prieto-Álamo, M. J., Jurado, J., Cordero, H., et al. (2014). The treatment with the probiotic Shewanella putrefaciens Pdp11 of specimens of Solea senegalensis exposed to high stocking densities to enhance their resistance to disease. Fish Shellfish Immun. 41, 209-221. doi: 10.1016/j.fsi.2014.08.019

Thompson, J., Gregory, S., Plummer, S., Shields, R. J., and Rowley, A. F. (2010). An in vitro and in vivo assessment of the potential of Vibrio spp. as probiotics for the Pacific white shrimp, Litopenaeus vannamei. J. Appl. Microbiol. 109, 1177-1187. doi: 10.1111/j.1365-2672.2010.04743.x

Utiswannakul, P., Sangchai, S., and Rengpipat, S. (2011). Enhanced growth of black tiger shrimp Penaeus monodon by dietary supplementation with Bacillus (BP11) as a probiotic. J. Aquac. Res. Dev. 2:006. doi: 10.4172/2155-9546.S1-006 
Van Doan, H., Hoseinifar, S. H., Dawood, M. A. O., Chitmanat, C., and Tayyamath,. K. (2017). Effects of Cordyceps militaris spent mushroom substrate and Lactobacillus plantarum on mucosal, serum immunology and growth performance of Nile tilapia (Oreochromis niloticus). Fish Shellfish Immun. 70 (Supplement C):87-94. doi: 10.1016/j.fsi.2017.09.002

Van Hai, N., Buller, N., and Fotedar, R. (2009). The use of customised probiotics in the cultivation of western king prawns (Penaeus latisulcatus Kishinouye, 1896). Fish Shellfish Immun. 27, 100-104. doi: 10.1016/j.fsi.2009.05.004

Vaseeharan, B., and Ramasamy, P. (2003). Control of pathogenic Vibrio spp. by Bacillus subtilis BT23, a possible probiotic treatment for black tiger shrimp Penaeus monodon. Lett. Appl. Microbiol. 36, 83-87. doi: 10.1046/j.1472-765X.2003.01255.x

Vendrell, D., Balcazar, J. L., Blas, I. D., Ruiz-Zzarzuela, I., Girones, O., and Muzquiz, J. L. (2008). Protection of Rainbow trout (Oncorhynchus mykiss) from lactococcosis by probiotic bacteria. Comp. Immunol. Microb. 31, 337-345. doi: 10.1016/j.cimid.2007.04.002

Verschuere, L., Rombaut, G., Sorgeloos, P. and Verstraete, W. (2000). Probiotic bacteria as biological control agents in aquaculture. Microbiol. Mol. Biol. R. 64, 655-671. doi: 10.1128/MMBR.64.4.655-671.2000

Vieira, F. N., Buglione, C. C., Mourino, J. P. L., Jatoba, A., Martins, M. L., Schleder, D. D., et al. (2010). Effect of probiotic supplemented diet on marine shrimp survival after challenge with Vibrio harveyi. Br. J. Veterinary Res. Animal Sci. 62, 631-638. doi: 10.1590/S0102-09352010000300019

Vine, N. G., Leukes, W. D., and Kaiser, H. (2006). Probiotics in marine larviculture. FEMS Microbiol. Rev. 30, 404-427. doi: 10.1111/j.1574-6976.2006.00017.x

Vinoj, G., Jayakumar, R., Chen, J. C., Withyachumnarnkul, B., Shanthi, S., and Vaseeharan, B. (2015). N-hexanoyl-L-homoserine lactonedegrading Pseudomonas aeruginosa PsDAHP1 protects zebrafish against Vibrio parahaemolyticus infection. Fish Shellfish Immun. 42, 204-212. doi: 10.1016/j.fsi.2014.10.033

Westerdahl, A., Olsson, J. C., Kjelleberg, S., and Conway, P. L. (1991). Isolation and characterization of turbot (Scophtalmus maximus)-associated bacteria with inhibitory effects against Vibrio anguillarum. Appl. Environ. Microb. 57, 2223-2228.
Wilson, B. A., Salyers, A. A., Whitt, D. D., and Winkler, M. E. (eds.). (2011). Bacterial Pathogenesis: A Molecular Approach. Washington: American Society for Microbiology (ASM).

Wu, Z., Jiang, C., Ling, F., and Wang, G. X. (2015). Effects of dietary supplementation of intestinal autochthonous bacteria on the innate immunity and disease resistance of grass carp (Ctenopharyngodon idellus). Aquaculture 438, 105-114. doi: 10.1016/j.aquaculture.2014. 12.041

Yan, L., Boyd, K. G., and Burgess, J. G. (2002). Surface attachment induced production of antimicrobial compounds by marine epiphytic bacteria using modified roller bottle cultivation. Mar. Biotechnol. 4, 356-366. doi: 10.1007/s10126-0020041-x

Yu, M., Li, Z., Lin, H., Wen, G., and Ma, S. (2009). Effects of dietary medicinal herbs and Bacillus on survival, growth, body composition, and digestive enzyme activity of the white shrimp Litopenaeus vannamei. Aquacult. Int. 17, 377-384. doi: 10.1007/s10499-008-9209-3

Zokaeifar, H., Balcázar, J. L., Saad, C. R., Kamarudin, M. S., Sijam, K., Arshad, A., et al. (2012). Effects of Bacillus subtilis on the growth performance, digestive enzymes, immune gene expression and disease resistance of white shrimp, Litopenaeus vannamei. Fish Shellfish Immun. 33, 683-689. doi: 10.1016/j.fsi.2012.05.027

Conflict of Interest Statement: The authors declare that the research was conducted in the absence of any commercial or financial relationships that could be construed as a potential conflict of interest.

Copyright (c) 2018 Hoseinifar, Sun, Wang and Zhou. This is an open-access article distributed under the terms of the Creative Commons Attribution License (CC BY). The use, distribution or reproduction in other forums is permitted, provided the original author(s) and the copyright owner(s) are credited and that the original publication in this journal is cited, in accordance with accepted academic practice. No use, distribution or reproduction is permitted which does not comply with these terms. 